\title{
Chapter 4 \\ The Beginning of High Mountain \\ Occupations in the Pyrenees. Human \\ Settlements and Mobility from \\ 18,000 cal BC to 2000 cal $\mathrm{BC}$
}

\author{
Ermengol Gassiot Ballbè, Niccolò Mazzucco, Ignacio Clemente Conte, \\ David Rodríguez Antón, Laura Obea Gómez, Manuel Quesada \\ Carrasco and Sara Díaz Bonilla
}

\begin{abstract}
During the last two decades, the archaeological research carried out in the Pyrenees challenged the traditional images of the past in this mountain area. The archaeological sequence of the range goes back and sites like Balma Margineda, treated until recently as an exception, now are seen as part of more global process. Actual data suggest that main valleys of the Pyrenean frequented by humans at the end of the last glacial period, with sites slightly over 1000 o.s.l. After the Younger Dryas, the human presence ascended to alpine and subalpine areas, in accordance with current archaeological data. The Neolisitation process was early in some hillsides, with intense remains of farming and pastoralism in many sites from dated in the second half of the 6th millennia cal BC. Human settlements like Coro Tracito, Els Trocs and El Sardo confirm the full introduction of agrarian activity in the central part of the Pyrenees between 5300 and 4600 cal BC. After 3500/3300 cal $\mathrm{BC}$ the indices oh sheepherding rises to alpine areas, with an abrupt increase of known archaeological sites in alpine areas, above the current timberline. This phenomena, as well as the signs of anthropic disturbance of the alpine environment in sedimentary sequences, suggests a more stable and ubiquitous human presence, probably largely associated with the development of mobile herding practices.
\end{abstract}

E. Gassiot Ballbè $(\bowtie)$ · D. Rodríguez Antón · L. Obea Gómez · M. Quesada Carrasco ·

S. Díaz Bonilla

Department of Prehistory, Autonomous University of Barcelona,

08193 Cerdanyola del Vallès, Bellaterra, Spain

e-mail: ermengol.gassiot@uab.cat

N. Mazzucco

Préhistoire et Technologie UMR 7055, Université Paris Ouest Nanterre La Défense,

Nanterre, France

I. Clemente Conte

Institució Milà I Fontanals, Spanish National Research Council (CSIC),

C/Egipcíaques 15, 08001 Barcelona, Spain

(C) The Author(s) 2017

J. Catalan et al. (eds.), High Mountain Conservation in a Changing World,

Advances in Global Change Research 62, DOI 10.1007/978-3-319-55982-7_4 
Keywords Mesolithic - Neolithic - High mountain human occupations • Farming $\cdot$ Pastoralism • Pyrenees

\subsection{Introduction}

The science of archaeology is undergoing constant change. In recent decades, our understanding of human populations in the late Pleistocene and the first half of the Holocene has increased considerably, owing both to new theoretical approaches and to an increase in the number of researchers. A greater volume of information now exists, for example about the changes of hunter-gatherer communities at the end of the last Ice Age and the development of the Neolithic in SW Europe (Bahn 1983; Galop 2006; Tzortzis and Delestre 2010). In connection with the latter period, in the last thirty years a considerable amount of data has accumulated about such diverse aspects as crop types, seasonality of the settlements, the mobility of flocks, people and objects, the impact of economic practices on the environment and the appearance of signs of social inequality.

Technical and methodological innovations have actively contributed to such a development; for example, the improvements in the methods of palaeocarpological remains recollection (and of palaeobotanical remains, in general) have altered the appearance and interpretations of many archaeological sites. Another is the introduction of new technologies and techniques for studying artefacts, such as the analysis of residues on pottery and lithic implements, the petrographic analysis of raw materials, traceological studies, etc. (Mazzucco et al. 2013). Also, the application of isotopic and DNA analysis to the study of animal and human osseous remains as well as of plants has improved our understanding of the processes of domestication of some species, livestock, and human mobility patterns, etc. (Edwards et al. 2007).

A further factor is related to the expansion of research, which has noticeably increased the number of empirical prehistoric records in southern Europe. New sites have been identified, some of which are now of great importance. One example is the early Neolithic site of La Draga, on the shore of Lake Banyoles (Antolín et al. 2014). Similarly, some geographic areas have received greater attention than in previous decades. This is the case of mountain areas in southern Europe, where numerous research projects are currently in progress. These programmes have largely embraced the growing sensibility of archaeological science towards understanding economic practices in the past, their relationship with the physical environment (geomorphology, climate, fauna and flora, etc.) and how this changed over time. In this context, it is important to identify the start of human presence in the different altitudinal zones in the mountain ranges after the last Ice Age and also the appearance of significant changes in the ways of life. One of these was undoubtedly the domestication of animals and plants in the first half of the Holocene. Recent publications reveal the current relevance of this archaeology of 
mountain areas such as the Pyrenees (Gassiot et al. 2016; Fortó and Vidal 2016; Clemente et al. 2014b; Tzortzis and Delestre 2010).

The archaeology of mountain areas in southern Europe is undergoing a kind of revolution that is very recent and yet cannot be adequately explained by general changes in the archaeological science. What is this phenomenon due to, therefore? Several factors have converged. On the one hand, some fortuitous finds have demonstrated that high mountain areas were occupied since very early times. The paradigmatic example is the find in summer 1991 in the Tissenjoch Glacier in South Tyrol, at 3,200 $\mathrm{m}$ altitude, of the remains of a man who was killed by an arrow wound between 3370 and 3100 cal BC (Kutschera and Miller 2003; Spindler 1995). Ötzi, as he is colloquially known, is currently one of the best known archaeological finds in Europe.

On the other hand, growing spatial sensibility of some social sciences (Santos 2000) has jelled in an archaeology that is increasingly aware that it needs to study how human societies live in a place, in an environment that influences them and which, at the same time, they transform (Redman et al. 2004; Folke 2006). This interest has been combined with a particular perception of the uniqueness of high mountain areas, which have slowly changed from being seen as practically pristine places to being viewed as areas full of life, including human life. In a certain way, the UNO's declaration of 2002 as "International Year of Mountains" attests this change in paradigm, which is also reflected in archaeology. Evidence of this is the proliferation of multidisciplinary programmes in the mountains of south-west Europe, studying the human occupations in long sequences, their impact on alpine and sub-alpine environments and the influence of climate variations (Galop 2006; Pèlachs et al. 2007, 2017; Bal et al. 2010; Palet et al. 2012; Cunill et al. 2012). In general, these different theoretical and methodological approaches share an interest in understanding past human activities in a particular physical space, high mountains, which they have shaped over time, together with climatic and ecological factors (Angelucci et al. 2013; Calastrenc et al. 2006; Fedele 1999; Le Couédic 2010; Leveau and Segard 2006; Orengo et al. 2014; Palet 2006; Palet et al. 2007, 2012; Rendu 2003; Rey 2006; Walsh et al. 2010).

The present study is a brief summary of archaeological data obtained in recent fieldwork in high altitude areas of the Pyrenees, especially in central and eastern parts of the mountain range. To delimit the long temporal sequence of the human population that is currently being documented, this paper will be focused on the first part of the sequence. This choice is connected with some of the questions posed by archaeological research in such regions in recent years. When did human occupation of high mountain areas begin? How was the livestock farming that currently characterises these areas introduced? In what way is this process related to the neolithisation process of nearby areas? From the beginnings of the twenty-first century, new approaches and techniques have been applied to answer these questions, obtaining results, as it will be shown below, that 10 or 12 years ago would have been unimaginable to most of the archaeologists. 


\subsection{The Start of Modern History: The Population of the Pyrenees in the Late Pleistocene and the First Half of the Holocene}

The archaeology of hunter-gatherer groups in the late Pleistocene in southern France and the Iberian Peninsula has traditionally paid considerable attention to the Pyrenean-Cantabrian region. However, this interest has focused on the foothills of the two mountain chains or, at the most, their outer ranges, relatively distant from their higher areas. Archaeological deposits with Palaeolithic remains have been known in both regions since the late nineteenth or early twentieth centuries, and many of them have been studied archaeologically (Bahn 1983; Fullola 1995). The situation in the interior of the ranges is very different, as they have not attracted the interest of researchers, perhaps because it was assumed that type of environment, especially during the cold conditions of the Upper Palaeolithic, would have been unattractive to human groups. In recent years that outlook is beginning to change (Mangado et al. 2005, 2009).

\subsubsection{Human Presence in the Valleys in the Late Pleistocene}

Evidence of human settlement in the Pyrenees in the Pleistocene is very scanty. Numerous Upper Palaeolithic sites certify the presence of hunter-gatherer groups during the last 20,000 years in the outer ranges of the Pyrenees and the foothills (Fullola et al. 2004; Utrilla and Montes 2007; Martzluff et al. 2012). Most of these archaeological deposits are situated in limestone caves and rock-shelters on the southern and northern edges of the mountain range, located at mid and low altitude. However, evidence for the penetration of these hunter-gatherer groups into the inner mountain areas are virtually absent (not even some lithic scatter or some isolated find), despite surface surveying has been carried out extensively in the Axial Pyrenees and the pre-Pyrenees since at least 10-15 years ago (Gassiot et al. 2016). This lack could be explained in several ways. One possible explanation could be that mountain areas did not attract the communities of different human species living in south-west Europe during the Pleistocene; this would have been particularly likely during the coldest periods when glaciers were much more extensive than today and covered most of the mountain zones. Another explanation is that the erosion of hillsides and valleys caused by the advance of glaciers removed the evidence of previous occupations.

Two main sites indicate human presence in the central zone of the Pyrenees during the late Pleistocene (Fig. 4.1). Both are situated in valleys. The first of these is in the open air, on a ridge in the Segre valley, in the town of Montlleó (Cerdanya) at $1140 \mathrm{~m}$ a.s.l. Archaeological excavations have identified two hunter-gatherer occupation phases dated between 18,360 and 16,700 cal BC (Mangado et al. 2005, 2009). They both took place in a cold humid climate that gradually ameliorated. 


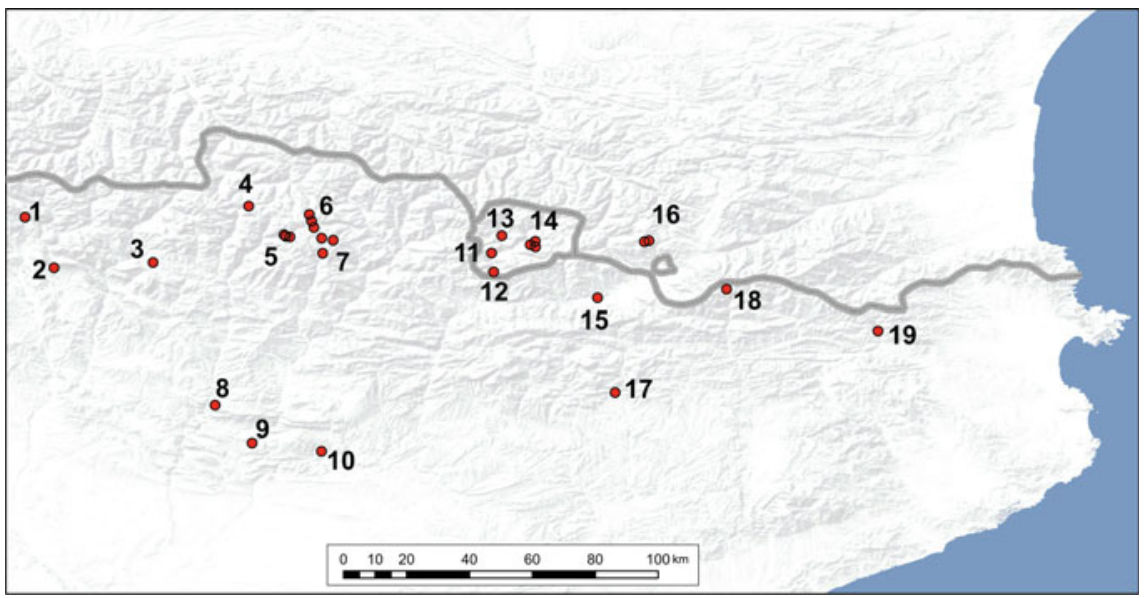

Fig. 4.1 Geographic localisation of the study area and the main archaeological sites mentioned in the text. 1 Coro Trasito, 2 La Puyascada, 3 Els Trocs, 4 Tuc deth Lac Redon, 5 Sites in the PNAESM (1): Covetes, Cova de Sarradé, Cova del Sardo, 6 Sites in the PNAESM (2): Abric del Lac Major de Saboredo II, Portarró, Obagues de Ratera, 7 Sites in the PNAESM (3): Girada Gran de Monestero, Abric de l'Estany de la Coveta I, Coma d'Espós, Dolmen de la Font dels Coms, 8 Cova Colomera, 9 Cova Gran de Santa Linya, 10 Cova del Parco, 11 Balma Margineda, 12 Juverri, 13 Cista de Segudet, 14 Sites in the VMPC, 15 Montlleó abd Sanavastre, 16 Sites in the Enveig mountains, 17 Font del Ros and Ca l'Oliaire, 18 Vall de Núria, 19 Balma del Serrat del Pont

The communities who lived there hunted mainly horses (Equus caballus) and to a lesser extent ibex (Capra pyrenaica pyrenaica) and red deer (Cervus elaphus). The implements found are knapped lithic fragments, with a significant representation of laminar debitage. The raw materials identified are flint from the head of the Llobregat river basin, in the southern Pre-Pyrenean range, jasper from the terraces of the River Tet in the north, and other materials from more distant sources, possibly in the Ebro valley or the Corberas and Narbonne-Sigean areas to the south and north of the range. Beads have been found made from marine mollusc shells obtained in the Mediterranean, except for one from an Atlantic source. The results are coherent with an occupation by nomadic communities who moved both north and south, possibly along the Segre valley. In this area, the pass across the mountains, Coll de la Perxa, is at $1570 \mathrm{~m}$ a.s.l. and may have been open at certain times of the year.

The second site is Balma Margineda (Fig. 4.1), a rock-shelter at 970 m altitude on the side of the River Valira, in Sant Julià de Lòria (Andorra). It was occupied from about 14,000 years ago to at least 7000 (Guilaine and Martzluff 1995, 2007) and thus its archaeological sequence covers the time from the Late Glacial period to the so-called Holocene Atlantic Optimum. The excavation identified a series of occupations by hunter-gatherer groups in the late Pleistocene (Levels 12-8) and early Holocene (Levels 7-4), covered by a thick Neolithic layer (Level 3). 
The oldest levels in the sequence indicate mountain vegetation formed by pine and juniper, at a time when the terminus of the Valira glacier may have been at 1,3001,400 $\mathrm{m}$ a.s.l. (Riera and Turu 2012). Both at that time and in later periods, the ibex was the main species hunted and consumed by the occupants of the rock-shelter. However, after $8000 \mathrm{cal} \mathrm{BC}$, the diet was diversified, and subsistence activities included fishing trout, gathering snails and, gradually and more intensely in successive occupations, plants such as sloe, hazel and cherry. Hunting also diversified in the Holocene, and even though ibex still predominated, roe deer and wild boar were also hunted. In sum, Balma Margineda appears to have been a settlement used in different periods by hunter-gatherer groups in a context of increasingly mild climates. Changes in the groups' industry and diet follow the general patterns seen in hunter-gatherer communities in the late Pleistocene and early Holocene in Iberia (Gassiot 2001).

\subsubsection{Initial Occupation of the High Zones in the Early Holocene}

Unlike Montlleó, Balma Margineda displays a long occupation sequence lasting millennia. In the transition from the Pleistocene to the Holocene, the human occupations became more intense and in fact until recently this site was considered paradigmatic of the mountain occupation in the Pleistocene-Holocene transition. In the last few years, archaeological surveying in the Claror, Perafita and Madriu valleys, also in Andorra (Palet 2006) and Aigüestortes i Estany de Sant Maurici National Park (Gassiot et al. 2014) have altered this view significantly. This fieldwork has succeeded in documenting evidence of human occupations in the sub-alpine and alpine altitudinal zones, at above $1800 \mathrm{~m}$ a.s.l. (Fig. 4.2).

The oldest evidence is Level 5 in Dolmen de la Font dels Coms, corresponding to a possible phase prior to building the megalithic grave. This site is at the head of the Baiasca valley, $6 \mathrm{~km}$ to the south-east of the park boundary, at $1840 \mathrm{~m}$ a.s.l. and $150 \mathrm{~m}$ below the watershed marking the western side of the river basin. Excavated in 2002 and 2003 by the High Mountain Archaeological Group (GAAM, in Catalan), it revealed a more complex archaeological sequence than initially expected, with great re-use of the monument in later periods (Rappalino et al. 2007). The oldest occupation is related to a possible post-hole found when a trench was opened in the tumulus to document its building method. The post-hole was clearly underneath the base of the mound and was circular in cross-section, with a diameter of nearly $20 \mathrm{~cm}$ and about $20 \mathrm{~cm}$ deep (Fig. 4.3). The top of the hole was surrounded by pieces of schist, a local metamorphic rock, some of which were placed vertically, marking the section of the hole. The sediment inside it contained a large number of small pieces of charcoal, thus darkening it and making it easily differentiable from the utterly barren earth surrounding it. One piece was dated to $8746-8563 \mathrm{cal}$ BC. The level containing the top of the post-hole yielded one of only two flint flakes found during the excavation of the site (Gassiot et al. 2014). 


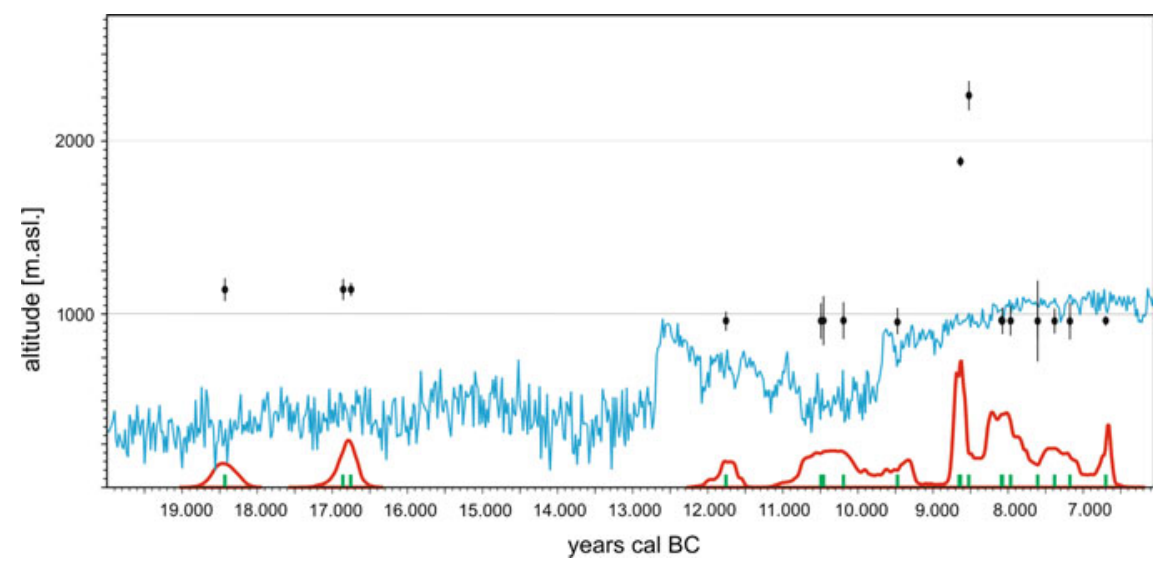

Fig. 4.2 Sum of probabilities of calibrated dates of Pleistocene and early Holocene human occupations in the axial Pyrenees. Individual dates are plotted in the $\mathrm{x}$-axis (green bars). Black circles also indicate the individual dates with their standard deviation and the altitude of the site (in the left y-axis). Greenland Ice Core Chronology 2005-GICC05 (Andersen et al. 2006; Rasmussen et al. 2006) is indicated in blue

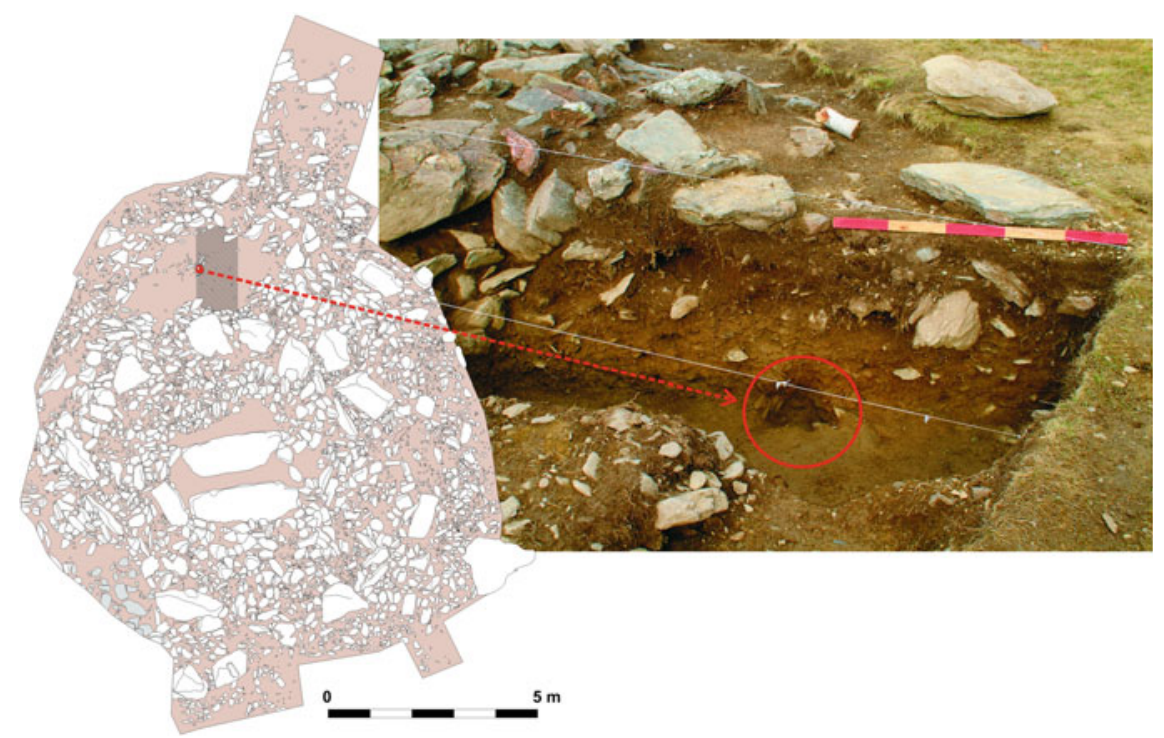

Fig. 4.3 Plant of the Dolmen of the Font dels Coms. The picture shows the open trench in the tomb. In red the hole that probably corresponds to a pole

A similar find was made in the medieval barn P009 at the Orrís de Perafita II site in Andorra. This site is in the Perafita valley, at 2,275 m altitude, in an area of pastures and bogs. The excavation of the architectonic structure showed that, below 
the walls visible on the surface, several occupation levels contained prehistoric remains. The lowest layer, Level 107, yielded flakes in local metamorphic rocks. This level was dated to $8764-8532$ and $8517-8478$ cal BC. The strata above it demonstrated the re-occupation of the site in later prehistoric periods. Lithic materials associated with this occupation are preliminarily classifiable as Notches and Denticulates Mesolithic (Orengo et al. 2014).

The third site with remains older than the Neolithisation process in the Pyrenees is Abric de l'Estany de la Coveta I (Fig. 4.4). This is a small rock-shelter formed by a mound of large granite boulders left by glacial activity in the late Pleistocene, on a small hill between two lakes, at $2430 \mathrm{~m}$ a.s.l. The interior of the shelter, with a surface area of a little over $5.5 \mathrm{~m}^{2}$, was occupied at several times in the past
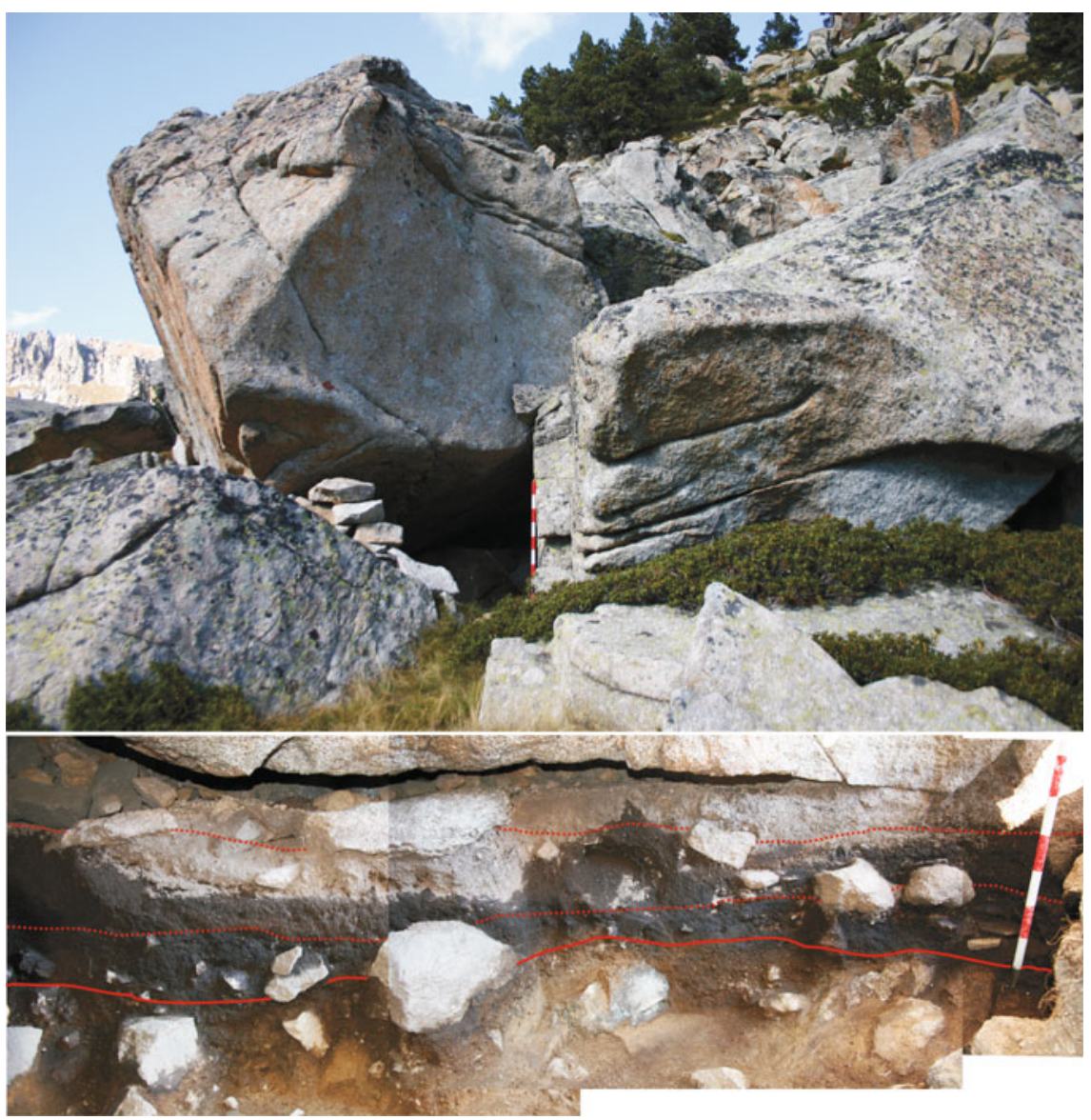

Fig. 4.4 a General image of the Abric de l'Estany of Coveta I, located in an area of large blocks accumulated during the last glacial period. b Detail of the east section of the excavation. The solid red line marks the Mesolithic occupation of the shelter. Dotted lines indicate the Neolithic occupation and the historical period (late medieval or medieval), respectively 
(Gassiot et al. 2014). The oldest phase of use was identified when a hearth was found in the place where the inner space connects with the small entrance passage. A pine charcoal fragment from this hearth, which was more or less circular in shape and a little over half a metre in diameter, was dated to 7001-6574 cal BC, over 3000 years before the Neolithic occupation.

A small quartz flake with thermal domes was found inside the hearth. Outside, in the layer that identified the occupation level, a further three chipped lithic fragments were found; together with the charcoal these form the only remains corresponding to this phase. All four lithic objects in the old level are small flakes less than $2 \mathrm{~cm}$ in size. Three of them were made in a dark brown flint that very probably comes from the Ebro Basin Oligocene-Miocene lacustrine formations. Microscopic study of one piece identified small notches and the characteristic polish caused by working dry hide. The action was clearly transversal and may indicate work connected with scraping the hide. As this small scraper is so small, it is likely that it would need to be hafted, otherwise it would have difficult to operate with it (Fig. 4.5).

Although the state of conservation of the charcoal in the hearth was quite poor, a sample was analysed. It practically all came from the wood of Pinus

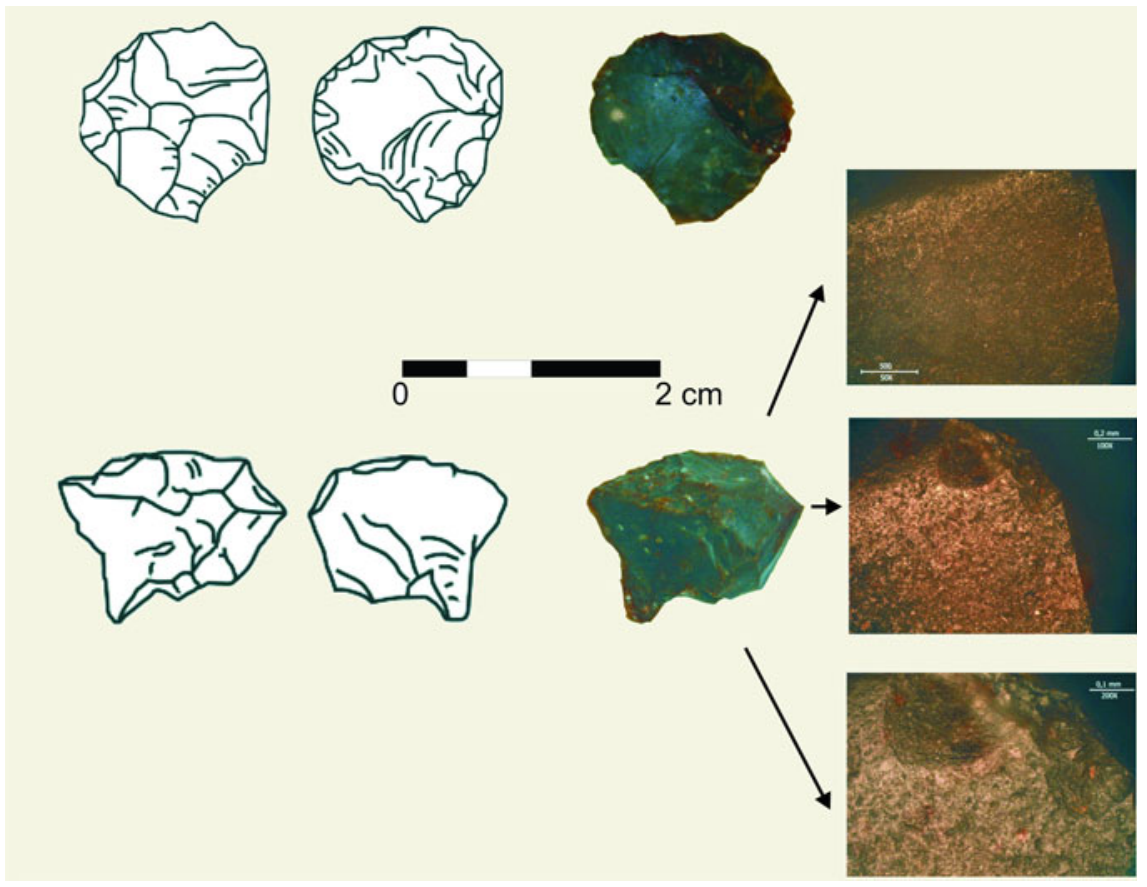

Fig. 4.5 Two of the lithic pieces recovered in the Mesolithic occupation of the Abric de l'Estany of Coveta I. At the top appears the photograph and drawing of the flint. At the bottom, the scraper shows the fingerprints of use from its distal edge, which was related to the processing of skin. From top to bottom $50 \times, 100 \times$ and $200 \times$, respectively. In the sketches: left, the dorsal side; right, the ventral. Photographs and drawings by Virginia García 
sylvestris/uncinata, thus suggesting the possible presence of arboreal vegetation in the proximity of the site. The growth rings displayed undulations caused by the pressure of the weight of snow. The rings were also very narrow, attesting the slow growth of trees in highland areas (Gassiot et al. 2010).

\subsection{The Arrival of the Neolithic: The Pyrenees as Farming Land}

Several centres of the initial domestication of animals and plants are now known on the different continents. Of these, the one that led to the adoption of domesticated species in the whole Mediterranean and Europe, in general, was located in the Near East. The gradual domestication of cereals, legumes, pigs, cattle and ovicaprids took place there about 10,000 or 9000 cal BC (Edwards et al. 2007; Haak et al. 2010; Zeder 2011). In the following 3000 years, these species rapidly spread beyond the "Fertile Crescent" to the Balkans, the Danube basin, the shores of the Mediterranean and North Africa, etc. The study of this process currently focus on: determining the time and mechanisms in which this expansion took place; the social and economic changes involved for the communities participating in the process; the relationship between groups of migrants or "colonists" and local communities; and the impact caused on the natural environment (Edwards et al. 2007; Haak et al. 2010; Zeder 2011).

Within these parameters, the study of the first agrarian communities in mountain areas, and in the Pyrenees in particular, is of great historical and anthropological importance. Until a few years ago, there was a somewhat non-explicit consensus that the range, like other mountain areas in the Iberian Peninsula, remained mostly on the sidelines of the first expansion of farming activities (Bahn 1983; Bertranpetit and Vives 1995; Jiménez 2006; Llovera 1986; Yáñez et al. 2002; Yáñez 2005; Orengo et al. 2014, Walsh et al. 2005). According to this concept, the adversity of mountain environments for the establishment of agriculture and their isolation would have marked the rate and form of the process, which to a great extent would have been much less intense and later than in the foothills. However, as it will be shown below, new data that is being collected thanks to recent archaeological projects is demonstrating that the Pyrenees were not marginal areas and that their Neolithisation has been a much more rapid and extensive process than previously thought.

\subsubsection{The First Neolithic Occupations in the Pyrenees}

The oldest evidence of prehistoric arable farming and animal husbandry in the Pyrenees and surrounding area is dated in the first half of the Holocene, at around 
5500 cal BC. Practically all the known sites are situated outside the central part of the mountain range. The most representative are Cueva de Chaves in the Sierra de Guara (Aragon), the open-air settlement of Font de Ros (Berga, Catalonia) and Dourgne II rock-shelter, at the head of the Aude Valley, in France. All of these are in areas at a medium altitude, in the valleys, at between 200 and $700 \mathrm{~m}$ a.s.l. (Guilaine et al. 1993).

At this time, Cueva de Chaves was a stable settlement, characterised by its mixed subsistence based on crops and livestock, complemented with small contributions from hunting and gathering (Mazzucco et al. 2015). It is an ancient settlement, with a series of occupations dated from 5700 to $5000 \mathrm{cal} \mathrm{BC}$, attesting an early Neolithisation of the outer ranges in the Pre-Pyrenees (Baldellou 2011; Mazzucco 2014). The cave probably mainly served as a place of human habitation as testified by the several hearths, pits and the other dwelling structures recovered. Palaeoenvironmental data suggest that human activity altered the surroundings of the cave by clearing land for pastures and crops in an area of mixed pine and oak woodland (López-García and López-Sáez 2000). The abundant archaeozoological evidence shows that domestic ovicaprids, and pigs and cattle in smaller proportions, were consumed inside the cave.

The small rock-shelter of Dourgne II is located at $710 \mathrm{~m}$ altitude in Roc de Dourgne. The excavations in the late 1970s and early 1980s revealed an occupation sequence dated between 6700 and 3500 cal BC (Guilaine et al. 1987). The start of the Neolithic occupations was dated to $5300 \mathrm{cal}$ BC. Several hearths and areas for lithic debitage were documented, in addition to silos re-used as waste pits. The subsistence evidence indicates a predominance of the use of domestic and wild fauna: together with livestock of ovicaprids and pigs, hunting wild boar was important in the different occupations. Unlike Cueva de Chaves, human activity did not significantly alter the environment of mixed woodland (Pinus sylvestris, Corylus sp., Juniperus sp., Taxus sp., Tilia sp. and Prunus sp.). Evidence of farming activity in the surrounding area was not documented either.

The site of La Font de Ros is situated on the outskirts of Berga (Barcelona), in the contact zone between the outer Pre-Pyrenean ranges and the central Catalan depression, at about $650 \mathrm{~m}$ altitude. Remains of several dwellings and storage structures, belonging to both the Mesolithic and Neolithic, were documented in an area of over $1000 \mathrm{~m}^{2}$. The latter were dated from 5500 to $4800 \mathrm{cal} \mathrm{BC}$. The conservation of osseous remains was very poor although some domestic species were identified. In contrast, domestic cereals were recovered, mainly dressed barley (Hordeum vulgare) and emmer (Triticum dicoccum). Other sites dated in the early Neolithic are Balma del Serrat del Pont (in Girona) (Alcalde et al. 2005) and the crock shelters of Hueso Raso and Forcas I and II (Utrilla and Mazo 2007). At Forcas II was found what might be the earliest evidence of pottery in the Pre-Pyrenees, in a stratum dated between 5990 and 5670 cal BC. However, proof of a Neolithic economy, with signs of domesticated animals and plants, did not appear until about 5500 cal BC.

Until recently, Balma Margineda was the only site dated in the sixth-millennium cal BC in the central Pyrenees (Guilaine et al. 1985). Excavations in the 
rock-shelter documented several early Neolithic occupations dated from 5700 to $5500 \mathrm{cal}$ BC, overlying the Mesolithic levels (Guilaine et al. 1995). These are surprisingly old, as they are also linked with clear evidence of domesticated goats and carpological remains of domestic cereals, as well as storage structures, hearths and pottery. The rock-shelter appears to have been used by communities that were "fully Neolithic", in the heart of the mountain range, at a very early date for the Neolithic in the whole of Iberia. This finding has provoked archaeological debates in which a possible route for the Neolithisation of the Iberian Peninsula through the Segre Valley has been proposed. However, oldest dates have often been questioned (Bernabéu 2006; Morales et al. 2010; Mazzucco 2014); a recent and detailed revision of the radiocarbon, stratigraphic and material culture data from the Balma Margineda, suggests that the first Neolithic occupation of the site should be dated not earlier than about 5500-5300 cal BC (Oms et al. 2016). These new dates appear more coherent with the chronological framework currently available for the Pyrenean area (Table 4.1).

Several recent finds have substantially confirmed this interpretation. On the one hand, archaeological surveying in high areas has located sites dated in the first half and middle of the sixth-millennium cal BC at over $1800 \mathrm{~m}$ a.s.l. On the other, the increase in research is revealing the existence of sites dated as well towards the last third of the sixth-millennium cal BC at between 1400 and $1600 \mathrm{~m}$ a.s.l. In the latter case, the most surprising aspect is that the existence of crops and livestock is widely found at these sites.

Two of the locations in the first group are SU 110 beneath Hut P009 at the site of Orris of the Perafita I peat bog, and Phase 9 at the Cova del Sardo. At the first of these, above a stratum with Mesolithic remains, the excavation under the medieval barn revealed a more recent prehistoric level that also contained some flakes. No structures were associated with these, and neither were potsherds or archaeozoological and archaeobotanical remains found. It may be a level representing visits to the area over which the buildings visible on the surface were built. A determination on a piece of charcoal dated the formation of this level between 5615 and 5475 cal BC (Orengo et al. 2014: 143). The second site, Cova del Sardo, is at 1,790 m a.s.l in the Sant Nicolau Valley, one of the central transversal valleys in the National Park. It is a small rock-shelter with a surface area of $19.3 \mathrm{~m}^{2}$ produced by glacial erosion of the granite bedrock. It is $60 \mathrm{~m}$ above the modern river bed on the lower part of the hillside (Fig. 4.6). The deposit was excavated from 2006 to 2008 (Gassiot et al. 2014) when a first occupation defined by a small hearth in a pit dug in the sediment was documented above a large deposit of till probably resulting from the collapse of lateral moraines in the late Pleistocene or early Holocene. Chipped lithic fragments were found in association with the hearth, but no potsherds or any other type of archaeological object. A piece of charcoal from the hearth was dated to a time almost contemporary with the Andorran site; between 5609 and 5376 cal BC.

In neither of these two cases is there any evidence linking the occupations with farming activities, although this might be explained by the small size of the deposits and poor conservation of the osseous remains at both sites. However, this contrasts 
4 The Beginning of High Mountain Occupations in the Pyrenees ...

Table 4.1 List of $14 \mathrm{C}$ dates from archaeological sites in the axial Pyrenees. All results have been calibrated using Oxcal 4.2 with the INTCAL13 curve

\begin{tabular}{|c|c|c|c|c|c|c|c|}
\hline Lab. code & Site & Type & Intervention & Material & $\begin{array}{l}\text { Result } \\
\text { (bp) }\end{array}$ & \pm & $\begin{array}{l}\text { Calibrated age } \\
95.4 \% \text { (cal } \\
\text { BC) }\end{array}$ \\
\hline Poz-28427 & Els Estanys & Hut M176 & Test pit & Charcoal & 3685 & 30 & 2192-1970 \\
\hline Poz-32018 & Els Estanys & $\begin{array}{l}\text { Fenced } \\
\text { M177 }\end{array}$ & Test pit & Charcoal & 3755 & 35 & $2285-2037$ \\
\hline Poz-18812 & Pleta de Bacives I & $\begin{array}{l}\text { Fenced } \\
\text { M151 }\end{array}$ & Test pit & Charcoal & 3755 & 35 & $2285-2037$ \\
\hline Poz-32023 & Els Estanys & Hut M217 & Test pit & Charcoal & 3760 & 35 & 2287-2039 \\
\hline Ly-8223 & La Padrilla & Hut 49 & Digging & Charcoal & 3810 & 40 & $2458-2062$ \\
\hline Poz-32017 & Els Estanys & $\begin{array}{l}\text { Fenced } \\
\text { M218 }\end{array}$ & Test pit & Charcoal & 3885 & 35 & 2469-2212 \\
\hline Poz-28426 & Els Estanys & Hut M175 & Test pit & Charcoal & 3885 & 30 & $2467-2284$ \\
\hline KIA-32335 & Cova de Sarradé & Cave & Test pit & Charcoal & 3945 & 35 & $2567-2306$ \\
\hline KIA-32341 & $\begin{array}{l}\text { Abric de les } \\
\text { Covetes }\end{array}$ & Shelter & Test pit & Charcoal & 3960 & 30 & $2569-2345$ \\
\hline Beta-290113 & $\begin{array}{l}\text { Abric del Lac } \\
\text { Major de } \\
\text { Saboredo II }\end{array}$ & Shelter & Test pit & Charcoal & 4010 & 40 & $2830-2459$ \\
\hline KIA-32348 & Cova del Sardo & Cave & Digging & Charcoal & 4090 & 35 & $2862-2493$ \\
\hline Poz-22584 & $\begin{array}{l}\text { Planells de } \\
\text { Perafita I }\end{array}$ & Sòl P067 & Test pit & Charcoal & 4105 & 35 & $2864-2501$ \\
\hline KIA-28280 & $\begin{array}{l}\text { Obagues de } \\
\text { Ratera }\end{array}$ & Shelter & Test pit & Charcoal & 4160 & 35 & $2878-2626$ \\
\hline KIA-36936 & Coma d'Espós & Hut 1 & Test pit & Charcoal & 4180 & 30 & $2885-2664$ \\
\hline KIA-26251 & Cova del Sardo & Cave & Test pit & Charcoal & 4210 & 35 & $2899-2675$ \\
\hline KIA-28276 & $\begin{array}{l}\text { Abric del } \\
\text { Portarró }\end{array}$ & Shelter & Test pit & Charcoal & 4255 & 40 & $3005-2692$ \\
\hline Ly-6242 & La Padrilla & $\begin{array}{l}\text { Hut/Fenced } \\
42\end{array}$ & Digging & Charcoal & 4370 & 30 & $3331-2885$ \\
\hline Beta-377578 & $\begin{array}{l}\text { Tuc deth Lac } \\
\text { Redon }\end{array}$ & Hut 2 & Test pit & Charcoal & 4400 & 30 & $3260-2915$ \\
\hline Beta-316510 & Els Trocs III & Cave & Digging & Seed & 4410 & 40 & $3325-2913$ \\
\hline Poz-22580 & $\begin{array}{l}\text { Orris de la } \\
\text { Torbera de } \\
\text { Perafita I }\end{array}$ & Hut P008 & Test pit & Charcoal & 4415 & 30 & $3312-2917$ \\
\hline Poz-32012 & $\begin{array}{l}\text { Planells de } \\
\text { Perafita I }\end{array}$ & $\begin{array}{l}\text { Fenced } \\
\text { P169 }\end{array}$ & Test pit & Charcoal & 4425 & 30 & $3321-2922$ \\
\hline Poz-22561 & Riu dels Orris I & Sòl M085 & Test pit & Charcoal & 4445 & 35 & $3333-2929$ \\
\hline KIA-40850 & Cova del Sardo 2 & Cave & Test pit & Charcoal & 4465 & 30 & $3335-3022$ \\
\hline KIA-29816 & $\begin{array}{l}\text { Abric de l'Estany } \\
\text { de la Coveta I }\end{array}$ & Shelter & Digging & Charcoal & 4475 & 30 & $3337-3027$ \\
\hline Mams-16167 & Els Trocs III & Cave & Digging & $\begin{array}{l}\text { Human } \\
\text { bone }\end{array}$ & 4512 & 25 & $3350-3101$ \\
\hline Ly-7064 & La Padrilla & Hut 75 & Digging & Charcoal & 4550 & 60 & $3497-3028$ \\
\hline KIA-32351 & Cova del Sardo & Cave & Digging & Charcoal & 4555 & 30 & $3481-3103$ \\
\hline KIA-37691 & Cova del Sardo & Cave & Digging & Charcoal & 4715 & 35 & $3630-3373$ \\
\hline KIA-36934 & Cova del Sardo & Cave & Digging & Charcoal & 4765 & 40 & 3639-3379 \\
\hline
\end{tabular}


Table 4.1 (continued)

\begin{tabular}{|c|c|c|c|c|c|c|c|}
\hline Lab. code & Site & Type & Intervention & Material & $\begin{array}{l}\text { Result } \\
\text { (bp) }\end{array}$ & \pm & $\begin{array}{l}\text { Calibrated age } \\
95.4 \% \text { (cal } \\
\text { BC) }\end{array}$ \\
\hline Poz-22579 & $\begin{array}{l}\text { Orris de la } \\
\text { Torbera de } \\
\text { Perafita I }\end{array}$ & Hut P008 & Test pit & Charcoal & 4905 & 35 & $3763-3637$ \\
\hline KIA-32342 & Cova del Sardo & Cave & Digging & Charcoal & 4945 & 35 & $3789-3650$ \\
\hline KIA-40816 & Cova del Sardo & Cave & Digging & Charcoal & 5000 & 30 & $3937-3700$ \\
\hline Mams-14856 & Els Trocs III & Cave & Digging & $\begin{array}{l}\text { Human } \\
\text { bone }\end{array}$ & 5005 & 27 & $3938-3706$ \\
\hline Mams-16160 & Els Trocs III & Cave & Digging & $\begin{array}{l}\text { Human } \\
\text { bone }\end{array}$ & 5008 & 23 & 3933-3709 \\
\hline Mams-16165 & Els Trocs III & Cave & Digging & $\begin{array}{l}\text { Human } \\
\text { bone }\end{array}$ & 5035 & 23 & $3950-3760$ \\
\hline KIA-26248 & Cova del Sardo & Cave & Test pit & Charcoal & 5060 & 40 & 3961-3764 \\
\hline KIA-32340 & Cova del Sardo & Cave & Digging & Charcoal & 5245 & 40 & $4227-3969$ \\
\hline Beta-319513 & Els Trocs II & Cave & Digging & Seed & 5580 & 40 & $4490-4340$ \\
\hline Beta-316511 & Els Trocs II & Cave & Digging & Seed & 5590 & 40 & $4500-4340$ \\
\hline Beta-316515 & Els Trocs II & Cave & Digging & Seed & 5590 & 40 & $4500-4340$ \\
\hline KIA-40815 & Cova del Sardo & Cave & Digging & Charcoal & 5635 & 35 & $4537-4367$ \\
\hline KIA-41134 & Cova del Sardo & Cave & Digging & Charcoal & 5645 & 25 & $4541-4373$ \\
\hline Poz-18807 & $\begin{array}{l}\text { Pleta de } \\
\text { Bacives I }\end{array}$ & Hut M152 & Test pit & Charcoal & 5660 & 40 & $4590-4368$ \\
\hline KIA-40817 & Cova del Sardo & Cave & Digging & Charcoal & 5685 & 35 & 4649-4447 \\
\hline KIA-36935 & Cova del Sardo & Cave & Digging & Charcoal & 5695 & 35 & $4651-4452$ \\
\hline KIA-40878 & Cova del Sardo & Cave & Digging & Charcoal & 5715 & 35 & 4679-4461 \\
\hline CNA-2520.1.1. & Coro Trasito & Cave & Test pit & Seed & 5830 & 35 & $4788-4590$ \\
\hline KIA-37690 & Cova del Sardo & Cave & Digging & Charcoal & 5850 & 40 & $4824-4600$ \\
\hline Beta-358571 & Coro Trasito & Cave & Test pit & Charcoal & 5990 & 40 & $4992-4786$ \\
\hline Beta-316514 & Els Trocs I & Cave & Digging & Seed & 6050 & 40 & $5056-4836$ \\
\hline Beta-295782 & Els Trocs I & Cave & Digging & Bone & 6060 & 40 & $5195-4842$ \\
\hline Beta-284150 & Els Trocs I & Cave & Digging & Seed & 6070 & 40 & $5202-4844$ \\
\hline Beta-316512 & Els Trocs I & Cave & Digging & Seed & 6080 & 40 & $5206-4847$ \\
\hline Beta-366546 & Coro Trasito & Cave & Test pit & Bone & 6150 & 40 & 5216-4993 \\
\hline Mams-16161 & Els Trocs I & Cave & Digging & $\begin{array}{l}\text { Human } \\
\text { bone }\end{array}$ & 6217 & 25 & $5294-5066$ \\
\hline Mams-16162 & Els Trocs I & Cave & Digging & $\begin{array}{l}\text { Human } \\
\text { bone }\end{array}$ & 6218 & 24 & $5294-5068$ \\
\hline Mams-16166 & Els Trocs I & Cave & Digging & $\begin{array}{l}\text { Human } \\
\text { bone }\end{array}$ & 6234 & 28 & $5303-5075$ \\
\hline Mams-16164 & Els Trocs I & Cave & Digging & $\begin{array}{l}\text { Human } \\
\text { bone }\end{array}$ & 6249 & 25 & $5310-5080$ \\
\hline Mams-16168 & Els Trocs I & Cave & Digging & $\begin{array}{l}\begin{array}{l}\text { Human } \\
\text { bone }\end{array} \\
\end{array}$ & 6249 & 28 & $5310-5078$ \\
\hline CNA-2944,1,1 & Coro Trasito & Cave & Test pit & Seed & 6269 & 33 & $5323-5081$ \\
\hline Mams-16159 & Els Trocs I & Cave & Digging & $\begin{array}{l}\text { Human } \\
\text { bone }\end{array}$ & 6280 & 25 & $5315-5215$ \\
\hline Mams-16163 & Els Trocs I & Cave & Digging & $\begin{array}{l}\text { Human } \\
\text { bone }\end{array}$ & 6285 & 25 & $5315-5215$ \\
\hline
\end{tabular}


4 The Beginning of High Mountain Occupations in the Pyrenees ...

Table 4.1 (continued)

\begin{tabular}{|c|c|c|c|c|c|c|c|}
\hline Lab. code & Site & Type & Intervention & Material & $\begin{array}{l}\text { Result } \\
\text { (bp) }\end{array}$ & \pm & $\begin{array}{l}\text { Calibrated age } \\
95.4 \% \text { (cal } \\
\text { BC) }\end{array}$ \\
\hline KIA-37689 & Cova del Sardo & Cave & Digging & Charcoal & 6525 & 45 & $5607-5374$ \\
\hline Beta-285100 & $\begin{array}{l}\text { Orris de la } \\
\text { Torbera de } \\
\text { Perafita I }\end{array}$ & Hut P009 & Test pit & Charcoal & 6570 & 40 & $5613-5473$ \\
\hline Ly-3288 & $\begin{array}{l}\text { Balma } \\
\text { Margineda }\end{array}$ & Cave & Digging & Charcoal & 6640 & 160 & 5885-5305 \\
\hline Ly-2839 & $\begin{array}{l}\text { Balma } \\
\text { Margineda }\end{array}$ & Cave & Digging & Charcoal & 6670 & 120 & 5806-5375 \\
\hline Ly-3290 & $\begin{array}{l}\text { Balma } \\
\text { Margineda }\end{array}$ & Cave & Digging & Charcoal & 6820 & 170 & $6040-5473$ \\
\hline Ly-3289 & $\begin{array}{l}\text { Balma } \\
\text { Margineda }\end{array}$ & Cave & Digging & Charcoal & 6850 & 160 & $6023-5487$ \\
\hline KIA-29818 & $\begin{array}{l}\text { Abric de l'Estany } \\
\text { de la Coveta I }\end{array}$ & Shelter & Digging & Charcoal & 7845 & 45 & $7001-6574$ \\
\hline Ly-2840 & $\begin{array}{l}\text { Balma } \\
\text { Margineda }\end{array}$ & Cave & Digging & Charcoal & 8390 & 150 & $7724-7060$ \\
\hline Ly-4402 & $\begin{array}{l}\text { Balma } \\
\text { Margineda }\end{array}$ & Cave & Digging & Charcoal & 8960 & 120 & $8447-7725$ \\
\hline Ly-2842 & $\begin{array}{l}\text { Balma } \\
\text { Margineda }\end{array}$ & Cave & Digging & Charcoal & 9250 & 160 & $9236-8007$ \\
\hline Poz- 22583 & $\begin{array}{l}\text { Orris de la } \\
\text { Torbera de } \\
\text { Perafita I }\end{array}$ & $\begin{array}{l}\text { Hut } \\
\text { P009107 }\end{array}$ & Test pit & Charcoal & 9360 & 50 & 8764-8478 \\
\hline KIA-23142 & $\begin{array}{l}\text { Dolmen de la } \\
\text { Font dels Coms }\end{array}$ & Open air & Digging & Charcoal & 9375 & 35 & $8746-8563$ \\
\hline Ly-3884 & $\begin{array}{l}\text { Balma } \\
\text { Margineda }\end{array}$ & Cave & Digging & Charcoal & 9900 & 110 & 9866-9174 \\
\hline Ly-4403 & $\begin{array}{l}\text { Balma } \\
\text { Margineda }\end{array}$ & Cave & Digging & Charcoal & 10340 & 130 & $10633-9692$ \\
\hline Ly-3364 & $\begin{array}{l}\text { Balma } \\
\text { Margineda }\end{array}$ & Cave & Digging & Charcoal & 10630 & 190 & $11005-10031$ \\
\hline Ly-2843 & $\begin{array}{l}\text { Balma } \\
\text { Margineda }\end{array}$ & Cave & Digging & Charcoal & 10640 & 260 & $11135-9767$ \\
\hline Ly-5418 & $\begin{array}{l}\text { Balma } \\
\text { Margineda }\end{array}$ & Cave & Digging & Charcoal & 11230 & 170 & $11450-10800$ \\
\hline Ly-4407 & $\begin{array}{l}\text { Balma } \\
\text { Margineda }\end{array}$ & Cave & Digging & Charcoal & 11320 & 120 & 11494-11006 \\
\hline Ly-4896 & $\begin{array}{l}\text { Balma } \\
\text { Margineda }\end{array}$ & Cave & Digging & Charcoal & 11690 & 90 & $11786-11393$ \\
\hline Ly-4898 & $\begin{array}{l}\text { Balma } \\
\text { Margineda }\end{array}$ & Cave & Digging & Charcoal & 11870 & 110 & $12035-11517$ \\
\hline OxA-9017 & Montlleó & Open air & Digging & Charcoal & 14440 & 80 & $15925-15415$ \\
\hline OxA-14034 & Montlleó & Open air & Digging & Molar & 15550 & 140 & $17185-16576$ \\
\hline OxA-X2234/52 & Montlleó & Open air & Digging & Molar & 16900 & 110 & $18717-18124$ \\
\hline
\end{tabular}

The source of the dating are mentioned in the main text for every site 

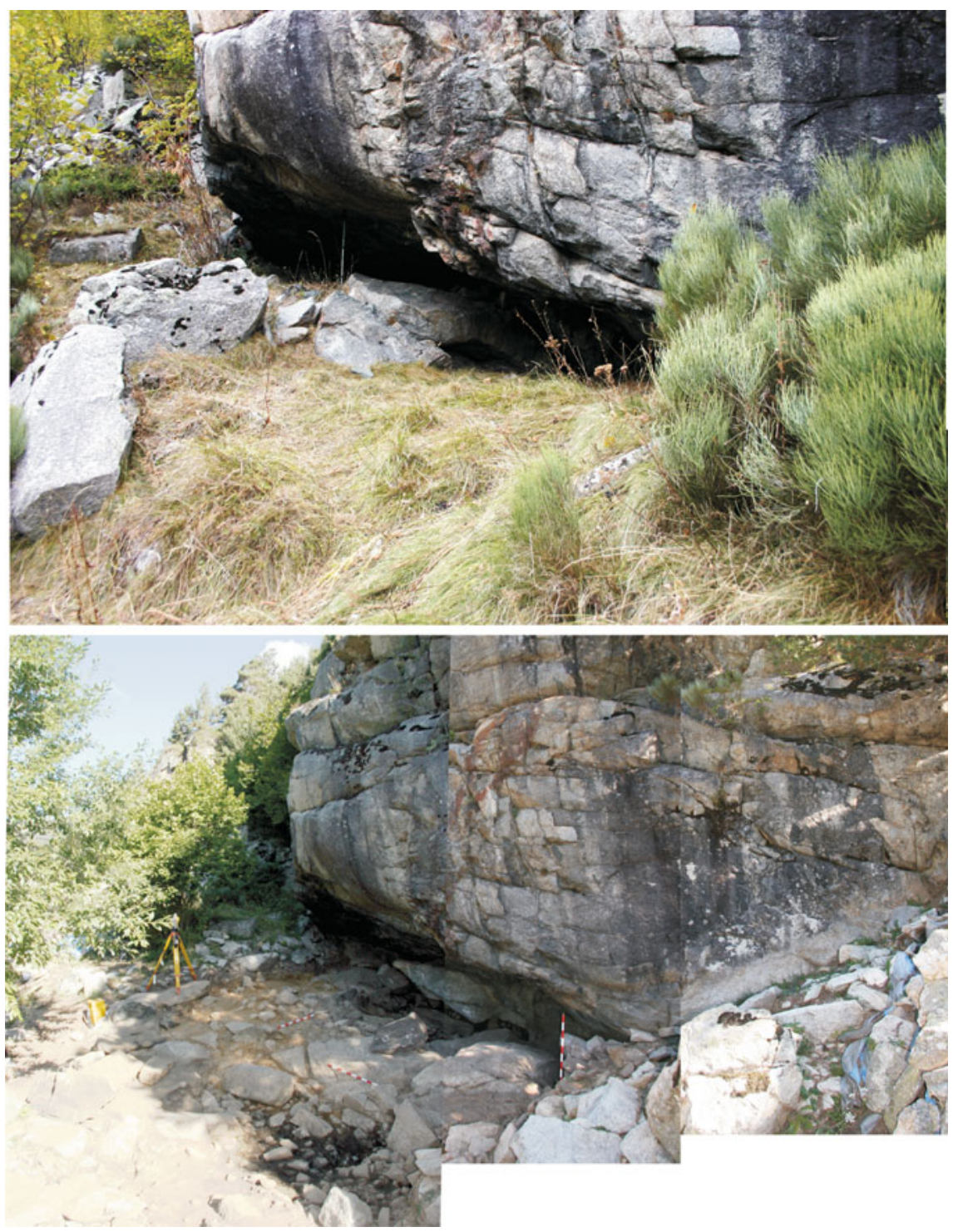

Fig. 4.6 General image of the Cova del Sardo. Above, at the time of its location in 2004. Bottom, in the final phase of its excavation, with the bare levels of the 5th Millennium cal BC outside the cavity

with the evidence found at Coro Trasito and Els Trocs. These two sites, of which the second is paradigmatic, are in the Pyrenees in Huesca, in Sobrarbe and the Benasque Valley (Ribagorza), respectively. The first is a west-facing entrance of a cave filled with Holocene sediments at $1548 \mathrm{~m}$ a.s.l. It is now a large rock-shelter 


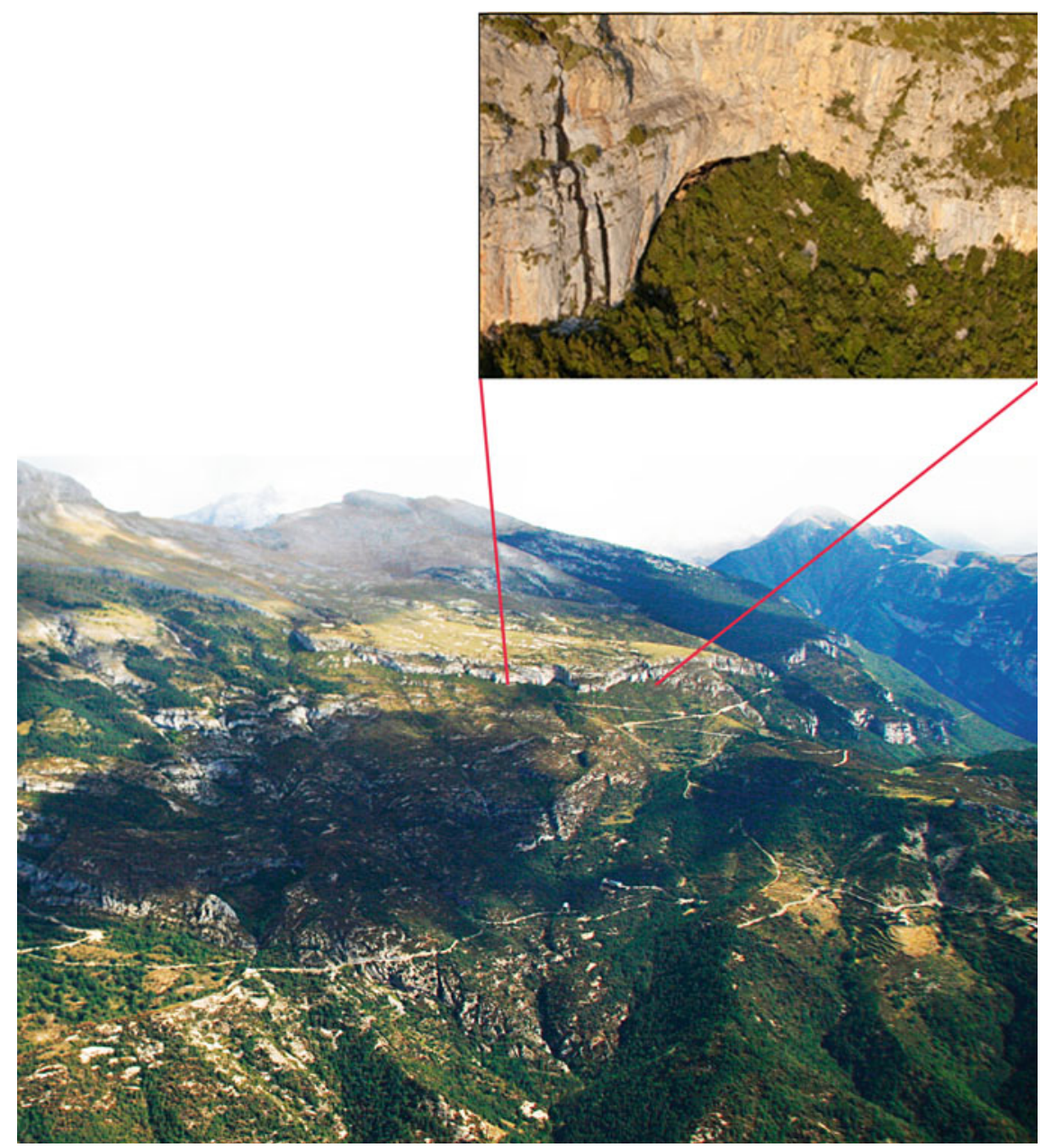

Fig. 4.7 Location and detail of the entrance of the cave of Coro Trasito

with a surface area available for human occupation of over $300 \mathrm{~m}^{2}$ (Figs. 4.7 and 4.8) A test excavation of $2.5 \times 1.5 \mathrm{~m}$ performed in two stages in 2011 and 2103 revealed a thick sequence of foumier sediments (burned layers of animal wastes mixed with soil) dated from 5300 to $4600 \mathrm{cal}$ BC (Clemente et al. 2014a, 2016). In this time, the cave entrance was used as a stable for livestock, for storage in small silos and as a dwelling. The accumulation of manure was so high that the rapid sedimentation blocked the passage to the inner part of the cave. The site was apparently abandoned in the mid fifth-millennium cal BC and not occupied again until nearly three millennia later, in about $1400 \mathrm{cal} \mathrm{BC}$.

Both the test and the proper excavation, currently in progress, have recorded a large variety of archaeological remains. These include a considerable amount of 


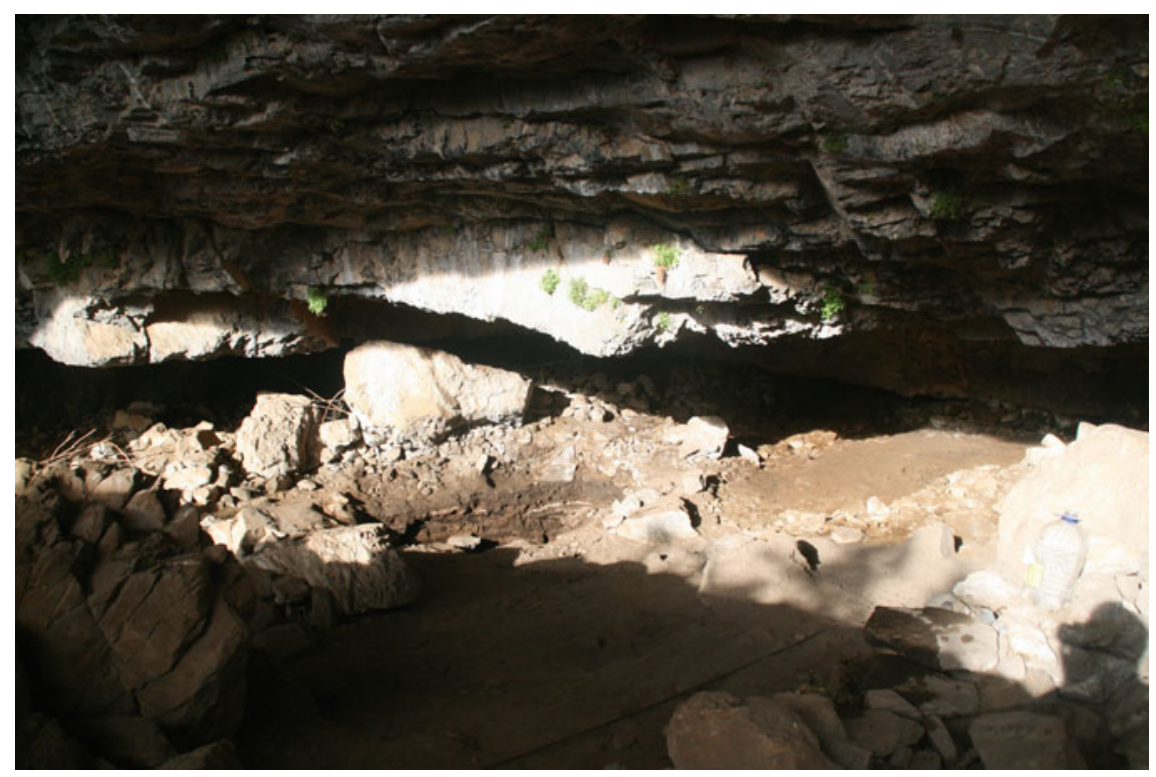

Fig. 4.8 Central section of the interior of Coro Trasito cornice, where excavations are currently being carried out. The survey of the year 2013 can be observed

pottery recipients in different sizes and shapes. While lithic objects are not very numerous, they reveal the use of raw materials from the Ebro basin, among other origins (Mazzucco et al. 2014). The type of sediment has enabled good conservation of osteological remains, resulting in the identification of a vast number of fragments of the animals consumed at the site. Their study is still in progress. The available radiocarbon dates show that in the oldest occupation phase currently known (5300-5100 cal BC), 90\% of the remains that have been determined taxonomically come from domestic species: sheep, goat, pig and cattle. This proportion decreases in following Neolithic occupations to $70 \%$. In the second millennium occupation cited above, the percentage of domestic fauna is still smaller; $55 \%$ of the identified remains. The wild animals consumed were mostly tortoise, red deer, roe deer and rabbit, among others.

During the test excavation a lot of carpological remains has been noted, despite sampling a relatively small amount of sediment; following the same trend as the fauna, the largest numbers of cultivated species and seeds came from the oldest occupation phase at the site. Naked barley (Hordeum vulgare var. nudum), free-threshing wheat (Triticum aestivum/durum/turgidum), and emmer (Triticum cf dicoccum) were documented as well as some hazelnuts and acorns. In later Neolithic levels, between 5000 and 4600 cal BC, the total number of seeds of domestic cereals decreases, but peas (Pisum sativum) have been found in some occupations and, above all, intense consumption of hazelnuts and, in some cases, of blackberries (Rubus fructicosus) has been documented in the most recent levels. 
In short, the first occupants of Coro Trasito practised a subsistence economy in which animal husbandry and crops played a significant role in the supply of food. Their material culture is also comparable with that of other "Neolithic" deposits of the same period in less mountainous regions.

Another site excavated recently which has altered the view of the Neolithic in the Pyrenees is Cova dels Trocs (Sant Feliu de Veri, Bisauri) (Fig. 4.1). It is at $1530 \mathrm{~m}$ a.s.l in a small hill in the plateau between the Turbón Massif in the south and the peaks of Vallivierna to the north (Rojo et al. 2013 and 2014). It is an elongated cave, $15 \mathrm{~m}$ long and $6 \mathrm{~m}$ wide, with a narrow entrance. Inside, the excavations performed since 2009 have documented three Neolithic occupation phases dated in 5300-4850, 5050-4350 and 3940-2915 cal BC. In the oldest phase, the cave floor was paved with cobblestones and occasionally with large potsherds. This means that the number of sherds retrieved, especially in this occupation, is quite spectacular and comes to tens of thousands. Large fires were lit on these pavements, and these have left large stains of ashes. The identified bone remains include a large number of domestic species: pig, sheep, cattle and goats, which form a large part of the total. Domestic cereal grains (wheat and barley) were also recovered, although the excavators tend to believe that they were introduced from outside the area by the occupants of the cave, who were mainly transhumant shepherds. Whatever the economic model was, the deposit in Cova dels Trocs is another example of an entirely "Neolithic" site in the central Pyrenees above an elevation of $1500 \mathrm{~m}$ in the late sixth-millennium cal BC (Rojo et al. 2013). Supporting this impression, in a palaeoecological test sounding outside the cave, Uría (2013) documented the clearance of woodland possibly to create pastures between 5500 and 5400 cal BC.

Occupations with "Neolithic" evidence at higher altitudes are dated some centuries later. At the Cova del Sardo (Fig. 4.1), in the Aigüestortes i Estany de Sant Maurici National Park, the first potsherds and remains of domestic cereals appear in the second occupational phase, called Phase 8 (Gassiot et al. 2012 and 2014). This phase is formed by a series of repeated occupations of the rock-shelter, from about 4800 to 4400 cal BC; during this period a small terrace was built in front of the cave, a combustion area where pine and juniper woods were repeatedly burnt. Moreover, two hearths were lit under the roof of the shelter. A single grain of barley (Hordeum vulgare) was recovered from the outer terrace, together with seeds of spontaneous plants (Galium aparine) and a few fragments of hazelnut shells. The pollen record inside the rock-shelter is indicative of relatively open vegetation, with a low proportion of arboreal pollen and taxa of secondary woodland and shrubs, contrasting with the situation during the rest of the occupations in the rock-shelter until the Middle Ages. Unfortunately, the acidity of the sediment has deteriorated faunal remains and only the presence of ovicaprids, and medium-sized mammals have been documented among the animals consumed. Potsherds are scarce, like the lithic assemblage. However, this shows that the implements were nearly always made away from the site and a considerable part of the raw materials was not from the immediate surroundings of the rock-shelter. Some of the flints came from the Ebro valley, as was also the case at Els Trocs (Mazzucco 2014). 
Another site that may have been occupied at a similar time is Covetes rock-shelter, near Cova del Sardo and also in the low part of the hillside in the Sant Nicolau Valley, at $1870 \mathrm{~m}$ a.s.1. A test excavation documented two phases of prehistoric occupations with pottery. The older one was covered by a thick barren layer, which was overlain by the more recent phase, dated to the early third-millennium cal BC (Gassiot et al. 2014).

However, for this first part of the Neolithic, evidence of occupation in the higher sub-alpine and alpine zones is practically absent. The only clear evidence is at the Cova del Sardo, in the bottom of a large valley and away from the cirques at the heads of the valleys and distant from the current timberline. In the Madriu valley in Andorra, Orengo (2014) cites a possible human occupation beneath a late Roman hut at the site of Pleta de Bacives I. However, the context is unclear, and the author provides no further information apart from the date. In any case, it does not alter the general view of the significant Neolithisation of the zone between 1500 and $1600 \mathrm{~m}$ a.s.l. in the late sixth-millennium cal BC, contrasting with lesser activity at higher altitudes in steeper valleys in the proximity of the modern alpine meadows.

\subsubsection{Approaching the Heights in the Late Neolithic}

In the fifth and fourth millennia, the presence of farming communities in medium-altitude mountains in the Pre-Pyrenees and Pyrenees becomes more intense and evident. Deposits are found in large caves, smaller sites and even in open-air structures. In the high Pyrenees, in addition to Coro Trasito (Clemente et al. 2014a, 2016) and Els Trocs (Rojo et al. 2013; Lancelotti et al. 2014), several sites are known at Juverri in Andorra, where numerous silos and evidence of farming activity have been documented (Fortó and Vidal 2016), all of them above $1200 \mathrm{~m}$ a.sl. At greater heights, the human use of Cova del Sardo continued in the fourth millennium, with an occasional construction outside the rock-shelter and the occupation of an adjacent rock-shelter at some point (Gassiot et al. 2014). In the Cerdanya valley, the remains of an open-air settlement dated in the second half of the fifth millennium have been documented at Sanavastre (1080 m a.s.1.). In Sierra Ferrera, in the Pre-Pyrenees of Aragon, the cave of Espluga de la Puyascada (1315 $\mathrm{m}$ a.s.1.) revealed occupations of a similar chronology (Baldellou 1987; Mazzucco et al. 2013). In the same way, numerous caves in the limestone areas in the outer mountain ranges of the southern Pre-Pyrenees were also used by human groups at this time, more intensely than in the early Neolithic.

A definite change took place in the human occupation of high mountain zones. This phenomenon has been documented very recently (Orengo et al. 2014; Rendu 2003) and has now begun to be addressed as a historical problem requiring an explanation (Gassiot et al. 2012, 2014). It can be seen in several aspects. First, the number of archaeological sites increases noticeably. In the area of Aigüestortes $i$ Estany de Sant Maurici National Park, nine sites are known with dates in the centuries following 3400 cal BC (Gassiot et al. 2014, 2016), of which one site, 
Cova del Sardo, contains two successive phases. This number contrasts with the single site dated in the previous phase of the Neolithic. The situation is similar in other high zones of the mountain range where systematic archaeological surveying has been carried out. In the Madriu-Perafita-Claror valley, six different sites are known for the period from 3300 to $2000 \mathrm{cal} \mathrm{BC} \mathrm{(Orengo} \mathrm{et} \mathrm{al.} \mathrm{2014).} \mathrm{In} \mathrm{the} \mathrm{Enveig}$ Mountains, in eastern Cerdanya, the three oldest occupations, all in the area of $\mathrm{La}$ Pradilla, are dated between 3500 and $2000 \mathrm{cal} \mathrm{BC}$. Second, this increase in the number of sites is also seen in their altitude. They are all above $2000 \mathrm{~m}$ a.s.l., except for three in Aigüestortes i Estany de Sant Maurici National Park, which are at between 1780 and $1980 \mathrm{~m}$. It, therefore, seems that this phenomenon can be extrapolated to at least the eastern half of the mountains.

In the Aigüestortes-Sant Maurici area, this increase in the number of occupations and their altitude takes place after 3400-3300 cal BC and becomes more noticeable after $3000 \mathrm{cal} \mathrm{BC}$ (Gassiot et al. 2014). The excavation at Abric de l'Estany de la Coveta I succeeded in documenting an occupation phase after the Mesolithic, in which a large hearth with abundant burnt pine wood was documented. Additionally, small soundings performed during surveying and surface archaeological documentation has identified the occupation of other rock-shelters between 3000 and $2400 \mathrm{cal} \mathrm{BC}$. These are Abric del Portarró (2284 m) (Fig. 4.9), Abric del Lac Major de Saboredo II (2367 m) and Abric d'Obagues de Ratera $(2312 \mathrm{~m}$ ) (Fig. 4.10). The same period is documented in a hearth underneath Hut 2 in a settlement dated in Roman times, Despoblat del Tuc deth Lac Redon (2411 m) and in the construction with the base of a stone wall and about $30 \mathrm{~m}^{2}$ of deposit at

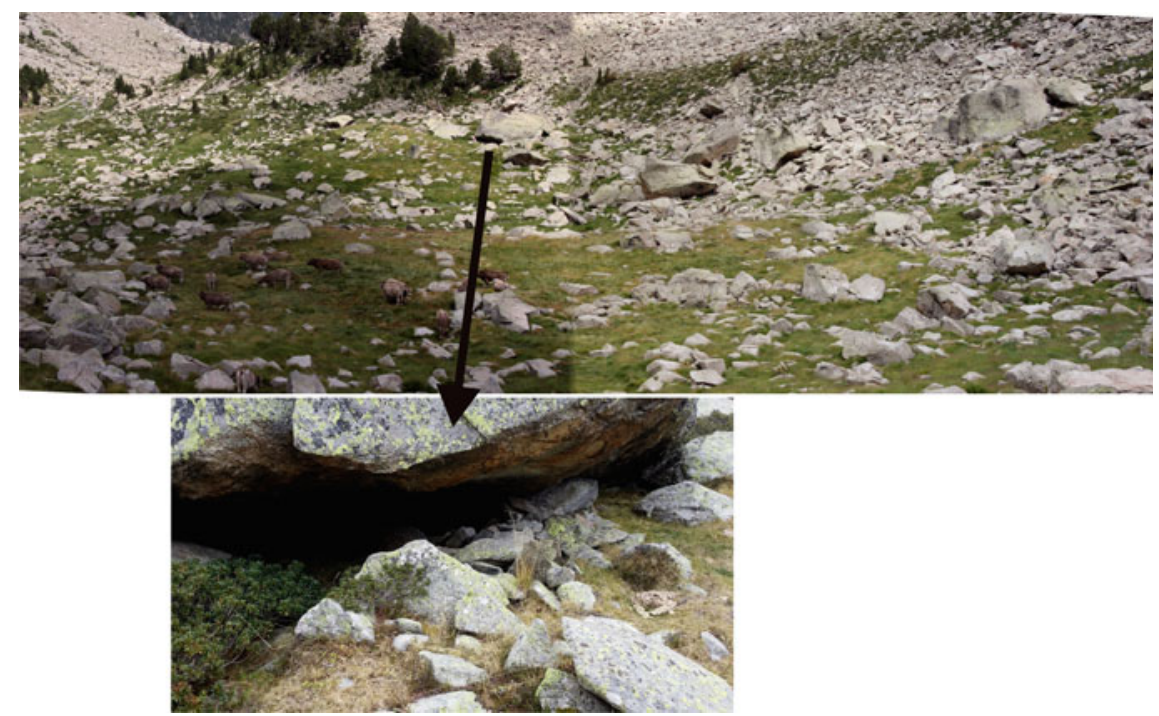

Fig. 4.9 General view of the Portarró archaeological site that contains several shelters with fencing and walls of the historical period scattered between the scree. In the enlarged image, the Abric del Portarró with an occupation of the end of the Neolithic 


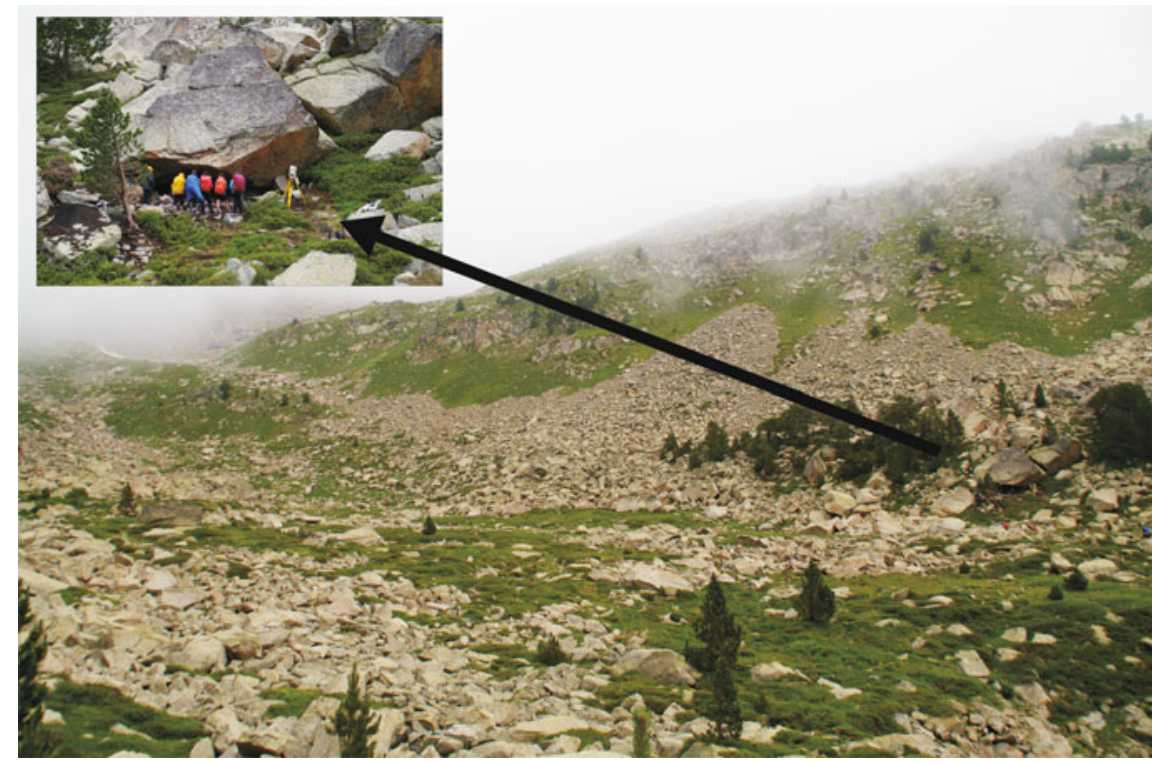

Fig. 4.10 Image of the site (and detail, in the enlargement) of the Abric d'Obagues de Ratera

Coma de Espós $(2230 \mathrm{~m})$. In lower altitudes, apart from the Cova del Sardo, occupations have been documented in Covetes and Cova de Sarradé (1980 m).

At the Cova del Sardo, the occupations inside and outside the rock-shelter continued in the fourth millennium and first half of the third millennium (Gassiot et al. 2014). This situation is quite different from the pattern at higher sites which seem to have been occupied in a single phase. The sequence at Cova del Sardo appears to reflect periods when the occupation was more stable alternating with others when the site may have been occupied in passing. Potsherds increase in number, in particular between 3900 and 3500 cal BC. The lithic assemblage displays some continuity in the parameters of the previous phase, although an increase in the use of allochthones chert types is seen (Mazzucco 2014). These lithologies came from the outer river basins in the Pre-Pyrenees and the Ebro valley. Occasional findings also indicate the possible presence of raw materials from the Rhone valley, suggesting that the site was integrated within a broader context of people mobility and artefacts and raw materials exchange. In general, it can be observed that the circulation of these lithic objects is mainly organised on south-north axis, through the valleys of the Segre's affluents. Crossing mobility pattern with faunal and palaeoecological data, it seems that some form of mobile herding was carried out involving a movement of flocks and people from plain areas and valley bottoms to high-altitudes. It has often remarked that such a pattern of mobility (Geddes 1983; Rojo et al. 2014) is similar to the movements of transhumant flocks in historical times, although such issue should be further investigated to understand the differences between prehistoric and medieval/modern herding 
models, on a social, economic and demographic level. On the basis of current data, there is no evidence for herding specialisation during Pyrenean Neolithic, but it seems that pastoral activities were integrated within a mixed-farming system, in which both crop and animal husbandry were practised to some extent.

Further east in the Pyrenees, this increase in human settlement in the second half of the fourth-millennium cal BC is also seen in the Enveig mountains. In Level 2 in Hut 75, at the site of La Padrilla, Rendu (2003) documented an occupation dated between 3500 and 3030 cal BC. This stratum consisted of dark sediment with ash and charcoal which was followed over $11 \mathrm{~m}^{2}$ under a construction visible on the surface and adjacent to some large boulders. The excavation was able to document four hearths delimited by stone circles or semicircles about $40 \mathrm{~cm}$ in diameter. This concentration of hearths might be the result of a repeated occupation of the site during a time that is still unknown. The use of the site in the late Neolithic was confirmed by another occupation. This is a stratum with abundant charcoal underneath Hut/Pen 42, $35 \mathrm{~m}$ away from the previous deposit. A piece of charcoal was dated to 3330-2885 cal BC.

In the Madriu-Perafita-Claror valley, the pattern is similar, with a clear increase in the number of archaeological sites after mid fourth-millennium cal BC. One of these is the level with charcoal identified underneath the early medieval hut P008 at Orris de la Torbera de Perafita I and which two radiocarbon determinations have situated between 3765-3640 and 3315-2920 cal BC (Orengo et al. 2014). In the same valley, at the nearby site of Planells de Perafita I, at $2223 \mathrm{~m}$ a.s.l., the same team of archaeologists identified the base of a stone wall around an area with an irregular shape, over $4 \mathrm{~m}$ in diameter, which they dated between 3325 and $2925 \mathrm{cal}$ BC. Potsherds were found in the layer associated with this occupation.

In general terms, in the three areas of the Pyrenees studied here, the archaeological evidence tends to disappear in the second half of the third-millennium cal BC (Fig. 4.11). The exception is the site of Els Estanys, in the Madriu Valley, at $2525 \mathrm{~m}$ a.s.1. It consists of an architectonic ensemble composed of four rooms, a pen and a surrounding wall. The five test excavations performed indicate an occupation between 2470-2290 and 2195-1970 cal BC. A grain of wheat (Triticum dicoccum) was found in one of the rooms, next to a hearth which had pottery associated with it (Orengo et al. 2014). A little over $1 \mathrm{~km}$ away, at the site of Pleta de Bacives (2528 $\mathrm{m}$ a.s.l.) an animal pen has been dated to the same period as the Els Estanys pen; 2284-2041 cal BC.

Following the occupation of these two sites, evidence of human occupation practically disappears from the Madriu-Perafita-Claror valley during the second and first millennia cal BC (Orengo 2010). The situation is similar in Aigüestortes i Estany de Sant Maurici National Park. Although some mid-second millennium sites are known, the number of settlements that have been identified is considerably smaller (Gassiot et al. 2014, 2016). A similar pattern has been recognised in the Enveig area (Rendu 2003). It seems that this phenomenon can be extrapolated to other parts of the Pyrenees, although it is in contrast with some palaeoecological evidence that indicates enhanced human impact on the environment. Still, we are not able to fully explain such discrepancy; possibly it is due to a limit in the survey 


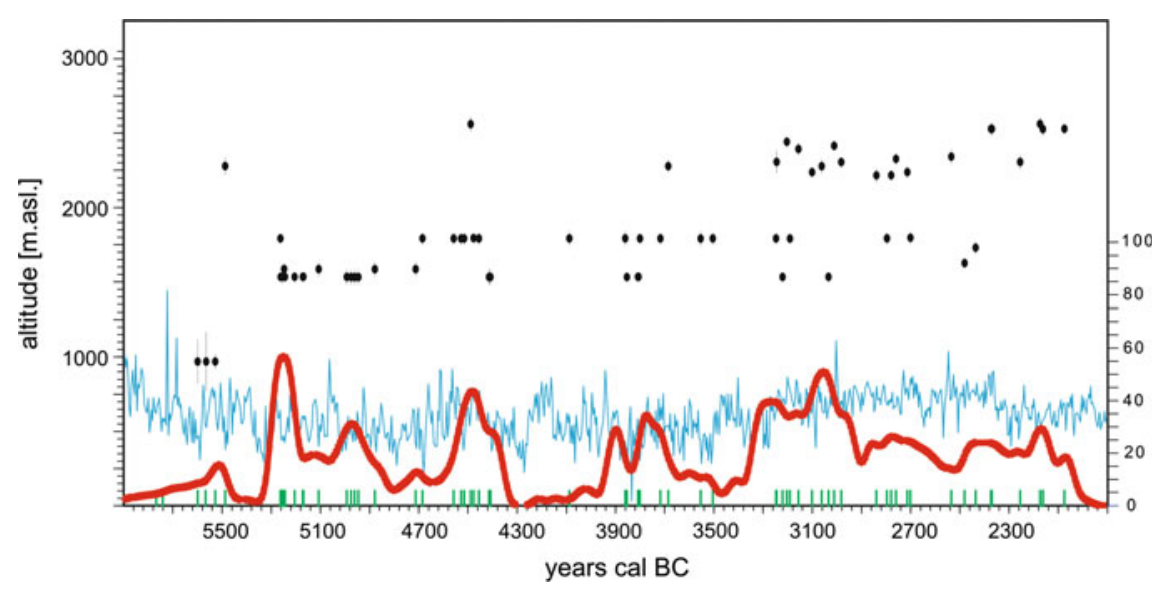

Fig. 4.11 Sum of probabilities of calibrated dates of Neolithic archaeological sites in the axial Pyrenees. Individual dates are plotted in the $\mathrm{x}$-axis (green bars). Black circles also indicate the individual dates with their standard deviation and the altitude of the site (in the left y-axis). Greenland Ice Core Chronology 2005-GICC05 (Andersen et al. 2006; Rasmussen et al. 2006) is indicated in blue

techniques adopted, or it might be influenced by the reoccupation over time of the same site, making difficult to discern prehistoric phases from medieval and modern ones, especially in open-air sites. However, a detailed analysis of this aspect is beyond the scope of the present chapter.

\subsection{Conclusions}

This study can be summed up briefly because, in a certain way, in itself, it has presented a series of main findings of the research carried out in high areas of the Pyrenees during the last 15-20 years. The archaeological records that fieldworks have generated have been described in chronological terms; Upper Palaeolithic presence in the high mountain areas of the Pyrenees appears remarkably reduced. Most of the evidence suggests the occupation of large caves ( $c a$. 19000-8000 year $\mathrm{BC}$ ), rock-shelters and open-air sites in the peripheral areas of the mountain, at lower and mid-altitudes; higher altitudes were not occupied probably because of harsh climate conditions, glaciers presence and the subsequent lack of attractive food options. Starting from the Holocene, the situation would change with a gradually, even if discontinuously, increasing human pressure high on mountain environments. Three sites, a rock-shelter and two open-air occupations, testify the presence of Mesolithic groups ( $\mathrm{ca}$. 8000-6500 year BC) in the alpine areas of the Pyrenees. Despite being very partial and limited data, they might indicate the occasional exploitation of high-altitudes by groups of hunter-gatherers; evidence for 
hunting activities (at least for regular big-game hunting practices) are still scarce, so the option of overnight occupations associated to cross-Pyrenean routes should also be taken into account. With Neolithisation ( $c a$. 5600-3000 year BC), human presence at both lower, mid- and high-altitudes gradually increase, with a diversification of sites of different duration and functionality associated with the extension of farming practices into mountainous zones. Around ca. 35002500 year BC, a sharp increasing in the number of sites and the signs of anthropic disturbance of the alpine environment is observed, suggesting a more stable and ubiquitous human presence, probably primarily associated with the development of mobile herding practices. Starting from the ca. 2000 year BC, a change in the settlement pattern probably occurs and, even if we are not still capable of fully explicate such process, the number of detected archaeological sites decrease quickly. Adopted survey techniques, medieval and modern reoccupation of prehistoric sites, changes in settlement strategy or the group's demography, lack of extensive research, all of them are factors that probably affect our site-detection capability. Future research might shed some light on this period.

Another consideration that can be drawn from the information obtained is that shortly after the end of the last important cold period, the Younger Dryas, human activity has been identified in sub-alpine and alpine zones. In these altitudes, the evidence of visits by hunter-gatherer groups is much weaker than in the valleys, and also more recent. However, these visits took place relatively quickly after the glaciers withdrew and these areas were re-colonised by vegetation. The information from the valleys is also of great interest and it suggests that they were occupied even in some of the colder periods in the late Ice Age. The results at Montlleó illustrate that the people who lived there were entirely familiar with the geography of the mountain range. Therefore, it was not an unplanned or occasional occupation.

A further aspect to be highlighted is the introduction of such essential practices in shaping the ecosystems as animal husbandry and arable farming. Until recently, information about sites with evidence of both activities in old chronologies, in the area of the western Mediterranean, was known in the outer ranges of the Pre-Pyrenees. Balma Margineda was, to some degree, an isolated site and it was not clear whether it was an isolated case. This perspective predominated, albeit not made explicit, and it was assumed that the expansion of the Neolithic, in social and economic terms, had largely been halted or slowed down in mountain areas. We now know that this picture was incorrect. At more recent times than the oldest sites in the foothills, but only a little more recent, sites like Coro Tracito, Els Trocs and El Sardo confirm the full introduction of agrarian activity in the central part of the Pyrenees. They indicate the intensity of Neolithisation on some hillsides, also used for arable farming, comparable with the situation in geographically proximate areas at much lower altitudes.

Finally, it is also interesting that the rates and characteristics of this process differ as a function of the altitude. In the sixth and fifth millennia, human presence in the alpine zone and upper part of the sub-alpine zone is rather tenuous, according to the current data. In contrast, from the mid-fourth millennium onwards, the number of sites and intensity of their occupation increases noticeably. This phenomenon, 
which has been fully described in the case of Aigüestortes i Estany de Sant Maurici National Park, appears to be comparable in other high mountain areas where fieldwork has also been intense and systematic.

In coming years, progress in our understanding of the human past of mountains in general and the Pyrenees, in particular, is sure to continue advancing rapidly. Ongoing research programmes at sites, the increase in archaeological surveying, greater cooperation between teams of archaeologists and also the increasingly interdisciplinary nature of the research are some of the factors that will contribute to this progress. Underpinning it is the growing awareness that high mountain areas have long been social spaces too. Empirical information is confirming it.

Acknowledgements This paper has been carried out in the frame of the GAAM/AGREST research activity. More specifically, this study is part of the projects "Análisi ecológico de la culturización del paisaje de alta montaña desde el Neolítico: los Parques Nacionales de montaña como modelo (CUL-PA)" funded by the Ministry of Agriculture, Food and Environment (Spain) and directed by J. Catalán and "Modelización de los espacios prehistóricos de montaña. Un SIG del patrimonio arqueológico y los territorios pastoriles" (HAR2015-66780-P, MINECO/FEDER) funded by the Ministry of Economy and Competitiveness (Spain) and directed by E. Gassiot.

\section{References}

Alcalde G, Molist M, Saña M (2005) Les ocupacions neolítiques de la Bauma del Serrat del Pont (La Garrotxa), Tribuna d'Arqueologia 2001-2002, 27-39

Andersen KA, Svensson A, Johnsen SJ, Rasmussen SO, Bigler M, Röthlisberger R, Ruth U, Siggaard-Andersen M-L, Steffensen JP, Dahl-Jensen D, Vinther BM, Clausen HB (2006) The greenland ice core chronology 2005, 15-42 ka. Part 1: constructing the time scale. Quat Sci Rev 25:3246-3257

Angelucci DE, Carrer F, Cavulli F, Delpero A, Foradori G (2013) Primi dati archeologici da una struttura pastorale d'alta quota in Val di Sole: il sito MZ005S (Mezzana, Trento) Mantova. In: Angelucci DE, Casagrande L, Colecchia A, Rottoli M (eds) APSAT 2. Paesaggi d'altura del Trentino. Evoluzione naturale e aspetti culturali. SAP - Società Archeologica, 2013, pp 141-162

Antolín F, Buxó R, Jacomet S, Navarrete V, Saña M (2014) An integrated perspective on farming in the early Neolithic lakeshore site of La Draga (Banyoles, Spain). Environ Archaeol 19(3): 241-255

Bahn P (1983) Pyrenean prehistory: a palaeoeconomic survey of the French sites. Aris \& Phillips, London

Bal MC, Rendu C, Ruas MP, Campmajo P (2010) Paleosol charcoal: reconstructing vegetation history in relation to agro-pastoral activities since the Neolithic. A case of study in the Eastern French Pyrenees. J Archeol Sci 37:1785-1797

Baldellou V (1987) Avance al estudio de la Espluga de la Puyascada, Bolskan: Revista de arqueología del Instituto de Estudios Altoaragoneses 4:3-42

Baldellou V (2011) La Cueva de Chaves (Bastarás - Casbas, Huesca). Saguntum extra 12:141-144

Bernabéu J (2006) Una visión actual sobre el origen y difusión del Neolítico en la Península Ibérica c. 5600-5000 cal BC. In: O. García-Puchol y J. E. Aura (dir.), El Abric de la Falguera (Alcoi, Alacant). 8000 años de ocupación humana en la cabecera del río Alcoi, Ajuntament d'Alcoi, Dipt d'Alacant, Alicante, CAM:189-211 
Bertranpetit J, Vives E (eds) (1995) Muntanyes i població. El passat dels Pirineus des d'una perspectiva multidisciplinària. I Simposi de Poblament dels Pirineus. Centre de Trobada de les Cultures Pirinenques, Andorra la Vella

Calastrenc C, Le Couédic M, Rendu C (2006) Archéologie pastorale en vallée d'Ossau. Problématiques, Méthodes et premiers resultats. Archéologie des Pyrénées Occidentales et des Landes 25:12-30

Clemente Conte I, Gassiot Ballbè E, Rey Lanaspa J, Mazzucco N, Obea Gómez L (2014a) "Cort o Transito"- Coro Trasito- o corral de tránsito: una cueva pastoril del Neolítico Antiguo en el corazón de Sobrarbe. In: Clemente Conte I, Gassiot Ballbè E, Rey Lanaspa J (eds) Sobrarbe antes de Sobrarbe: pinceladas de historia de los Pirineos (pp 11-32). Centro de Estudios de Sobrarbe (CES), Instituto de estudios Altoaragoneses (IEA) editores. Cometa S.A., Zaragoza

Clemente I, Gassiot E, Rey J (eds) (2014b) El Sobrarbe antes de Sobrarbe: Pinceladas de historia de los Pirineos. Centro de Estudios de Sobrarbe, Zaragoza

Clemente Conte I, Gassiot Ballbè E, Rey Lanaspa J, Obea Gómez L, Viñerta Crespo A, Saña Segui M (2016) Cueva de Coro Trasito (Tella-Sin, Huesca): Un asentamiento pastoril en el Pirineo central con ocupaciones del Neolítico Antiguo y del Bronce Medio. In: Lorenzo JI, Rodanés JM (eds) I Congreso Arqueologia y Patrimonio Aragonés. Colegio Oficial de Doctores y Licenciados en Filosofía y Letras y en Ciencias de Aragón, Zaragoza, pp 71-80

Cunill R, Soriano JM, Bal MC, Pèlachs A, Pérez-Obiol R (2012) Holocene high-altitude vegetation dynamics in the Pyrenees: a pedoanthracology contribution to an interdisciplinary approach. Quat Int 289(2013):60-70

Edwards CJ, Bollongino R, Scheu A, Chamberlain A, Tresset A, Vigne J-D, Baird JF, Larson G, Ho SYW, Heupink TH, Shapiro B, Freeman AR, Thomas MG, Arbogast RM, Arndt B, Bartosiewicz L, Benecke N, Budja M, Chaix L, Choyke AM, Coqueugniot E, Döhle HJ, Göldner H, Hartz S, Helmer D, Herzig B, Hongo H, Mashkour M, Özdogan M, Pucher E, Roth G, Schade-Lindig S, Schmölcke U, Schulting RJ, Stephan E, Uerpmann HP, Vörös I, Voytek B, Bradley DG, Burger J (2007) Mitochondrial DNA analysis shows a Near Eastern Neolithic origin for domestic cattle and no indication of domestication of European aurochs. Proc R Soc Lond B: Biol Sci 274:1377-1385

Fedele F (1999) Le ricerche del Pian dei Cavalli nel contesto del popolamento preistorico della Valchiavenna, Atti del II Convegno Archeologico Provinciale, vol 3, Grosio, pp 17-34

Folke C (2006) Resilience: the emergence of a perspective for social-ecological systems analyses. Glob Environ Change 16:253-267

Fortó A, Vidal À (eds) (2016) Comunitats agrícoles al Pirineu. L'ocupació humana a Juberri durant la segona meitat del V millenni cal AC (Feixa del Moro, Camp del Colomer i Carrer Llinàs 28, Andorra). Edicions del Govern d'Andorra, Andorra la Vella

Fullola JM, Garcia-Argüelles P, Serrat D, Bergadà MM (1995) El Paleolític i l'Epipaleolític al vessant meridional dels Pirineus catalans. Vint anys de recerca a la franja pirinenca sud; interrelacions amb les àrees circundants. In: Xè Colloqui Internacional d'Arqueologia de Puigcerdà. Cultures i Medi, de la Prehistòria a l'Edat Mitjana. Vint anys d'Arqueologia pirinenca. Institut d'Estudis Ceretans, Puigcerdà, pp 159-176

Fullola JM, Petit MA, Mangado X, Bartrolí R, Albert RM, Nadal J (2004) Occupation épipaléolithique microlamellaire de la grotte du Parco (Alòs de Balaguer, Catalogne, Espagne). Actes du XIV Congrès UISPP, section 7, Lieja 2001, Le Mésolithique, BAR International Series, 1302, Oxford, 2004, 121-128

Galop D (2006) La conquête de la montagne pyrénéenne au Néolithique. In: Guilaine J (ed) 2006, Populations Néolithiques et enivrements, Ed. Errance, Paris: 279-295

Gassiot E (2001) El canvi cap a l'explotació del litoral. PhD Dissertation, Departament de Prehistòria, UAB. http://www.tdx.cat/handle/10803/5498

Gassiot E, Pèlachs A, Bal MC, Garcia V, Julià R, Rodríguez-Antón D, Astrou ACh (2010) Dynamiques des activités anthropiques sur un milieu montagnard dans les píreneénne occidentales catalanes pendant la période de la préhistoire: une approche multidisciplinair. Archéologie de la Montagne Européenne, Bibliothèque d'Archéologie de la Méditerranéenne et Africaine 4:33-43 
Gassiot E, Rodríguez Antón D, Burjachs F, Antolín F, Ballesteros A (2012) Poblamiento, explotación y entorno natural de los estadios alpinos y subalpinos del Pirineo central durante la primera mitad del Holoceno. Cuaternario y Geomorfología 26(3-4):26-42

Gassiot E, Rodríguez Antón D, Pèlachs A, Bal MC, Garcia V, Julià R, Pérez R, Mazzucco N (2014) La alta montaña durante la Prehistoria: 10 años de investigación en el Pirineo catalán occidental. Trabajos de Prehistoria 71(2):262-282

Gassiot E, Clemente I, Mazzucco N, Garcia D, Obea L, Rodríguez Antón D (2016) Surface surveying in high mountain areas, Is it possible? Some methodological considerations. Quat Int 402:35-45

Geddes DS (1983) Neolithic transhumance in the Mediterranean Pyrenees. World Archeol 15:51-66

Guilaine J, Martzluff M (1995) Les excavacions a la Balma de la Margineda (1979-1991) I-III. Ministeri d'Afers Socials i Cultura, Andorra

Guilaine J, Martzluff M (2007) Les excavacions a la Balma de la Margineda (1979-1991) IV. Ministeri d'Afers Socials i Cultura, Andorra

Guilaine J, Martzluff M, Geddes D, Coularou J, Le Gall O (1985) Postglacial Environments, Settlement and Subsistence in the Pyrenees: the Balma Margineda, Andorra. In: Bonsal C (ed) 1985: Mesolithic in Europe, Edinbourgh, pp 561-571

Guilaine J, Barbaza M, Gasco J, Geddes D, Jalut G, Vaquer J, Vernet J-L (1987) L'abri du Roc de Dourgne: Écologie des cultures du mésolithique et du néolithique ancien dans une vallée montagnarde des Pyrénées de l'est. In: Premières communautés paysannes en Méditerranée occidentale: Actes du Colloque International du CNRS (Montpellier, 26-29 avril 1983). Paris, CNRS Éditions

Guilaine J, Barbaza M, Gasco J, Geddès D, Coularou J, Vaquer J, André J, Jalut G, Vernet JL (1993) Dourgne: derniers chasseurs-collecteurs et premiers éleveurs de la Haute-vallée de l'Aude. Centre d'Anthropologie des Sociétés Rurales, Archeologie en Terre de l'Aude, Carcassone

Haak W, Balanovsky O, Sánchez JJ, Koshel S, Zaporozhchenko V, Adler CJ, Der Sarkissian CSI, Brandt G, Schwarz C, Nicklish N, Dresely V, Fritsch B, Balanovska E, Villems R, Meller H, Alt KW, Cooper A, The Genographic Consortium (2010) Ancient DNA from European early neolithic farmers reveals their near eastern affinities. PLoS Biol 8(11). doi:10.1371/journal. pbio. 1000536

Jiménez J (2006) La imagen de los espacios de alta montaña en la prehistoria: El caso de los Pirineos Catalanes Occidentales, Treball d'investigació de doctorat, Dept. Prehistòria, UAB, Bellaterra. http://hdl.handle.net/2072/12393

Kutschera W, Miller W (2003) Isotope language of the Alpine Iceman investigated with AMS and MS. Nucl Instrum Methods Phys Res B 204:705-719

Lancelotti C, Balbo AL, Madella M, Iriarte E, Rojo-Guerra M, Royo JI, Tejedor C, Garrido R, García I, Arcusa H, Pérez-Jordà G, Peña-Chocarro L (2014) The missing crop: investigating the use of grasses at Els Trocs, a Neolithic cave site in the Pyrenees (1564 m asl). J Archaeol Sci 42(2014):456-466

Le Couédic M (2010) Les pratiques pastorales d'altitude dans une perspective ethnoarchéologique. Cabanes, troupeaux et territoires pastoraux pyrénéens dans la longue durée. $\mathrm{PhD}$ Dissertation, Université François-Rabelais de Tours. http://tel.archives-ouvertes.fr/tel-00543218/fr/

Leveau P, Segard M (2006) Le pastoralisme antique autourdu col du Petit-Saint-Bernard. In: Alpis Graia: archéologie sans frontières au col du Petit-Saint-Bernard. Seminario di chiusura, Aosta, 2-4 marzo 2006, Aosta, pp 153-161

Llovera X (1986) La Feixa del Moro (Juberri) i el Neolític Mig-Recent a Andorra. Tribuna d'Arqueologia, pp 14-24

Lopéz-García P, Lopéz-Sáez JA (2000) Le paysage et la phase Épipaléolithique-Mésolithique dans les Pré-Pyrénées Aragoinaises et le Bassin Moyen de l'Ebre à partir de l'analyse palynologique, Les derniers chaasseurs-cueilleurs d'Europe occidentale (13000-5500 av.j.c.). Actes du Colloque International de Desançon, 23-25 octobre 1998, Environment, societés et 
archéologie, 1, Besançon: Presses Universitaires-Fanc-Comtoises, Collection Annales Littéraires, pp 278-287

Mangado X, Mercadal O, Fullola JM, Esteve X, Langlais M, Nadal J, Estrada A, Bergadà MM (2005) Montlleó (La Cerdanya, Lleida), un yacimiento magdaleniense de alta montaña al aire libre en los Pirineos catalanes. In: Bicho N, Corchón, MS (eds) O Paleolítico: Actas do IV Congresso de Arqueologia Peninsular (Faro, 14 a 19 de Setembro de 2004). Faro: Centro de Estudos de Patrimonio, Departamento de Historia, Arqueologia e Patrimonio, Universidade do Algarve, pp 471-480

Mangado X, Fullola JM, Mercadal O, Bergadà MM, Langlais M, Esteve X, Estrada A, Nadal J, Tejero JM, Grimao J (2009) Montlleó. El primer poblament del Pirineu català. Cicle de Conferències. Patrimoni arqueològic i arquitectònic a les terres de Lleida 2009:48-61

Martzluff M, Martínez-Moreno J, Guilaine J, Mora R, Casanova J (2012) Transformaciones culturales y cambios climáticos en los Pirineos catalanes entre el Tardiglaciar y Holoceno antiguo: Aziliense y Sauveterriense en Balma de la Margineday Balma Guilanyà. Cuaternario y Geomorfología 26(3-4):61-78

Mazzucco N (2014) The Human Occupation of the Southern Central Pyrenees: a traceological approach to flaked stone assemblages. PhD Dissertation, Universitat Autònoma de Barcelona, 432 pp. http://www.tdx.cat/handle/10803/287893

Mazzucco N, Clemente-Conte I, Baldellou V, Gassiot E (2013) The management of lithic resources during the V millennium cal BC at Espluga de la Puyascada (La Fueva, Huesca). Preistoria Alpina 47:57-67

Mazzucco N, Ortega Cobos D, Clemente Conte I, Gassiot Ballbè E, Baldellou V, Rojo Guerra M (2014) Pautas de movilidad en el pirineo central durante el Neolítico antiguo: una aproximación a partir de los recursos líticos. In: Clemente Conte I, Gassiot Ballbè E, Rey Lanaspa J (eds) Sobrarbe antes de Sobrarbe, pinceladas de historia de los Pirineos, pp 107-126. Centro de Estudios de Sobrarbe (CES) e Instituto de Estudios Altoaragoneses (IEA) editores. Cometa S.A. Zaragoza

Mazzucco N, Clemente I, Gassiot E, Gibaja JF (2015) Insights into the economic organization of the first agro-pastoral communities of the NE of the Iberian Peninsula: a traceological analysis of the Cueva de Chaves flaked stone assemblage. J Archaeol Sci 2:353-366

Morales JI, Fontanals M, Oms FX, Vergès JM (2010) La chronologie du Néolithique ancien cardial du Nord-Est de la péninsule Ibérique. Datations, problématique et méthodologie. L'Anthropologie 114:427-444

Oms X, Gibaja JF, Mazzucco N, Guilaine J (2016) Revisión radiocarbónica y cronocultural del Neolítico Antiguo de la Balma Margineda (Aixovall, Andorra). Trabajos de Prehistoria 73 (1):29-46

Orengo H (2010) Arqueología de un paisaje cultural pirenaico de alta montaña. Dinámicas de ocupación del valle del Madriu-Perafita-Claror (Andorra). Tesi doctoral inèdita. Institut català d'Arqueologia Clàssica - Universitat Rovira i Virgili

Orengo HA, Palet JM, Ejarque A, Miras Y, Riera S (2014) Shifting occupation dynamics in the Madriu-Perafita-Claror valleys. Quat Int 353:140-152

Palet JM (2006) Stratégies de la recherche archéologique en haute montagne: les projets "Champsaur" (Alpes du sud) et "vallée du Madriu/ la Vansa - Serra del Cadi" (Pyrénées). In Alpis Graia: archéologie sans frontières au col du Petit-Saint-Bernard. Seminario di chiusura, Aosta, 2-4 marzo 2006, pp 381-385

Palet JM, Ejarque A, Miras Y, Riera S, Euba I, Orengo H (2007) Formes d'ocupació d'alta muntanya a la vall de la Vansa (Serra del Cadí - Alt Urgell) i a la vall del Madriu-Perafita-Claror (Andorra): estudi diacrònic de paisatges culturals pirinencs. Tribuna d'Arqueologia 2006-2007:229-253

Palet JM, Julià R, Riera S, Ejarque A, Orengo H, Miras Y, Garcia A, Allée Ph, Reed J, Marco J, Marqués MA, Furdada G, Montaner J (2012) Landscape systems and human land-use interactions in mediterranean highlands and littoral plains during the late holocene: integrated analysis from the InterAmbAr Project (North-Eastern Catalonia). J Ancient Stud 3:305-310 
Pèlachs A, Soriano JM, Nadal J, Esteban A (2007) Holocene environmental history and human impact in the Pyrenees. Contrib Sci 3:423-431

Pèlachs A, Pérez-Obiol R, Soriano JM, Cunill R, Bal M-C, García-Codron JC (2017) The role of environmental geohistory in high mountain landscape conservation. In: Catalan J, Ninot JM, Aniz MM (eds) Challenges for high mountain conservation in a changing world. Springer, pp 107-129

Rappalino V, Marugan CM, Gassiot E, Font J, Cazanueve X, Ll Cases, Bringué JM, Adell JA (2007) Un passeig per la història de Llavorsí. Ajuntament de Llavorsí i Pagès, Lleida

Rasmussen SO, Andersen KK, Svensson AM, Steffensen SP, Vinther BM, Clausen HB, Siggaard-Andersen M-L, Johnsen SJ, Larsen LB, Dahl-Jensen D, Bigler M, Röthlisberger R, Fischer H, Goto-Azuma K, Hansson ME, Ruth U (2006) A new Greenland ice core chronology for the last glacial termination. J Geophys Res 111:D06102. doi:10.1029/2005JD006079

Redman ChL, Fish PR, James SR (eds) (2004) The archaeology of global change: the impact of humans on their environment. Smithsonian Institute Press

Rendu C (2003) La montagne d'Enveig, une estive pyrénéenne dans la longue durée. Canet-sur-mer, Trabucaire, p 333

Rey P-J (2006) Occupations et circulations pre-romaines autour du col du petit Saint-Bernard; methode et premiers resultats d'une etude archeologique et sedimentaire de la montagne alpine. In: Alpis Graia: archeologie sans frontieres au col du Petit-Saint-Bernard. Seminario di chiusura, Aosta, 2e4 marzo 2006, pp 77-117

Riera S, Turu V (2012) Cambios en el paisaje del Valle de Ordino al inicio del Holoceno: Evolución geomorfológica, paleovegetal e incendios de época mesolítica (NW del Principado de Andorra, Pirineos orientales). Cuaternario y Geomorfología 26:3-4

Rojo Guerra M, Peña Chocarro L, Royo Guillén JI, Tejedor Rodríguez C, Martínez García, de Lagrán I, Arcusa Magallón H, Garrido Pena R, Moreno M, Mazzuco N, Gibaja Bao JF, Ortega D, Kromer B, Alt KW (2013) Pastores trashumantes del Neolítico Antiguo en un entorno de alta montaña: secuencia crono-cultural de la Cova de Els Trocs (San Feliú de Veri, Huesca). BSAA, LXXIX, pp 9-54

Rojo M, Arcusa H, Peña L, Royo JI, Tejedor C, García I, Garrido R, Moreno-García M, Pimenta C, Mazzucco N, Gibaja JF, Pérez G, Jiménez I, Iriarte E. Art KW (2014) Los primeros pastores trashumantes de la Alta Ribagorza. In: Clemente I, Gassiot E, Rey J (eds) El Sobrarbe antes de Sobrarbe: Pinceladas de historia de los Pirineos, pp 127-151. Centro de Estudios de Sobrarbe (CES) e Instituto de Estudios Altoaragoneses (IEA) editores. Cometa S.A. Zaragoza

Santos M (2000) La naturaleza del espacio. Ariel, Barcelona

Spindler K (1995) The man in the ice: the discovery of a 5000-year-old body reveals the secrets of the stone age. Crown Publishers, Inc. (NYC)

Tzortzis S, Delestre X (eds) (2010) Archéologie de la Montagne Européenne. Bibliothèque d'Archéologie de la Méditerranéenne et Africaine 4. Aix-en-Provence, Errance

Uría Blanco N (2013) Registros sedimentarios como indicadores paleoambientales y de la actividad antrópica durante la Neolitización: La Cueva de Els Trocs y su entorno (Abella, Huesca). CKQ Estudios de Cuaternario/Leioa 3:123-134

Utrilla P, Montes L (2007) La période 19000-14000 BP dans le bassin de l'Ėbre. Bulletin de la Société préhistorique française 104(4):797-807

Utrilla P, Mazo C (2007) La Peña de Las Forcas de Graus (Huesca). Un asentamiento reiterado desde el Magdaleniense Inferior hasta el neolítico antiguo. Saldvie 7:9-37

Walsh K, Mocci F, Tzortzis S, Bressy C, Talon B (2010) Les Écrins, un territoire d'altitude dans le contexte des Alpes occidentales de la Préhistoire récente à l'âge du Bronze (Hautes-Alpes, France). In: Tzortzis S \& Delestre X (eds) Table ronde internationale "Archéologie de la montagne européenne", Sep 2008, Gap, France. Errance/Centre Camille Jullian, Paris/Aix-en-Provence, Bibliothèque d'Archéologie Méditerranéenne et africaine 4:211-225

Walsh K, Mocci F, Tzortis S, Bressy C, Talon B, Richer S, Court-Picon M, Dumass V, Palet Martinez JM (2005) Les Écrins, un territoire d'altitude dans le contexts des Alpes occidentales de la Préhistoire récente à l'âge du Bronze. In: Tzortzis S, Delestre X (eds) 2010. Archéologie 
de la Montagne Européenne. Bibliothèque d'Archéologie de la Méditerranéenne et Africaine 4. Aix-en-Provence, Errance, pp 211-225

Yáñez C (2005) El Neolític. In: dins Belenguer E (eds) Història d’Andorra Barcelona, Edicions 62, pp 51-76

Yáñez C, Burjachs F, García C, Díaz N, Juan J, Malgosa A, Isidro A, Matamala JC (2002) El món funerari al final del V millenni a Andorra: la tomba de Segudet (Ordino), Cypsela, vol 14, pp 175-194

Zeder MA (2011) The origins of agriculture in the Near East. Curr Anthropol 52(4):221-235

Open Access This chapter is licensed under the terms of the Creative Commons Attribution 4.0 International License (http://creativecommons.org/licenses/by/4.0/), which permits use, sharing, adaptation, distribution and reproduction in any medium or format, as long as you give appropriate credit to the original author(s) and the source, provide a link to the Creative Commons license and indicate if changes were made.

The images or other third party material in this chapter are included in the chapter's Creative Commons license, unless indicated otherwise in a credit line to the material. If material is not included in the chapter's Creative Commons license and your intended use is not permitted by statutory regulation or exceeds the permitted use, you will need to obtain permission directly from the copyright holder.

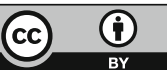

